\title{
HR-LCMS-Based Metabolite Profiling, Antioxidant, and Anticancer Properties of Teucrium polium L. Methanolic Extract: Computational and In Vitro Study
}

\author{
Emira Noumi ${ }^{1,2}$, Mejdi Snoussi ${ }^{1,3, *} \mathbb{C}$, El Hassane Anouar ${ }^{4}{ }^{\circledR}$, Mousa Alreshidi ${ }^{1}$,

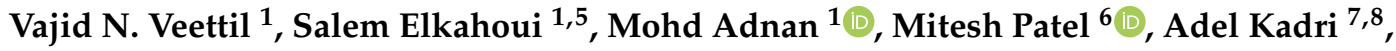
Kaïss Aouadi ${ }^{9,10}$, Vincenzo De Feo ${ }^{11, *(1)}$ and Riadh Badraoui ${ }^{1,12,13}$

1 Department of Biology, College of Science, University of Hail, P.O. Box 2440, Ha'il 2440, Saudi Arabia; eb.noumi@uoh.edu.sa (E.N.); mousa.algladi@gmail.com (M.A.); vajidnv@gmail.com (V.N.V.); salemelkahoui@gmail.com (S.E.); drmohdadnan@gmail.com (M.A.); riadh.badraoui@fmt.utm.tn (R.B.)

2 Laboratory of Bioressources: Integrative Biology and Recovery, High Institute of Biotechnology-University of Monastir, Monastir 5000, Tunisia

3 Laboratory of Genetics, Biodiversity and Valorisation of Bioressources, High Institute of Biotechnology-University of Monastir, Monastir 5000, Tunisia

4 Department of Chemistry, College of Science and Humanities in Al-Kharj, Prince Sattam bin Abdulaziz University, Al-Kharj 11942, Saudi Arabia; anouarelhassane@yahoo.fr

5 Laboratory of Bioactive Substances, Center of Biotechnology of Borj Cedria, BP 901, Hammam lif 2050, Tunisia

6 Bapalal Vaidya Botanical Research Centre, Department of Biosciences, Veer Narmad South Gujarat University, Surat 395007, India; patelmeet15@gmail.com

7 Department of Chemistry, College of Science and Arts in Baljurashi, Albaha University, Albaha 65527, Saudi Arabia; lukadel@yahoo.fr

8 Department of Chemistry, Faculty of Science of Sfax, University of Sfax, BP 1117, Sfax 3000, Tunisia

9 Department of Chemistry, College of Science, Qassim University, Buraidah 51452, Saudi Arabia; kaiss_aouadi@hotmail.com

10 Laboratory of Heterocyclic Chemistry, Natural Products and Reactivity, Department of Chemistry, Faculty of Science of Monastir, University of Monastir, Monastir 5019, Tunisia

11 Department of Pharmacy, University of Salerno, Via Giovanni Paolo II, 132, Fisciano, 84084 Salerno, Italy

12 Section of Histology-Cytology, Medicine College of Tunis, Tunis El Manar University, Road Djebel Lakhdhar, La Rabta-Tunis 1007, Tunisia

13 Laboratory of Histo-Embryology and Cytogenetic, Medicine College of Sfax, Sfax University, Sfax 3029, Tunisia

* Correspondence: m.snoussi@uoh.edu.sa (M.S.); defeo@unisa.it (V.D.F.); Tel.: +966-530-463-706 (M.S.); Fax: +39-089-969-602 (V.D.F.)

Received: 25 September 2020; Accepted: 3 November 2020; Published: 5 November 2020

\begin{abstract}
In this study, we investigate the phytochemical profile, anticancer, and antioxidant activities of Teucrium polium methanolic extract using both in vitro and in silico approaches. The results showed the identification of 29 phytochemical compounds belonging to 13 classes of compounds and 20 tripeptides using High Resolution-Liquid Chromatography Mass Spectrometry (HR-LCMS). 13R-hydroxy-9E,11Z octadecadienoic acid, dihydrosamidin, valtratum, and cepharantine were the main compounds identified. The tested extract showed promising antioxidant activities $\left(\right.$ ABTS-IC $\mathrm{I}_{50}=0.042 \mathrm{mg} / \mathrm{mL}$; 1,1-diphenyl-2-picrylhydrazyl (DPPH)-IC $\mathrm{I}_{50}=0.087 \mathrm{mg} / \mathrm{mL}, \beta$-carotene- $\mathrm{IC}_{50}=0.101 \mathrm{mg} / \mathrm{mL}$ and FRAP-IC $50=0.292 \mathrm{mg} / \mathrm{mL}$ ). Using both malignant Walker 256/B and MatLyLu cell lines, T. polium methanolic extract showed a dose/time-dependent antitumor activity. The molecular docking approach revealed that most of the identified molecules were specifically binding with human peroxiredoxin 5 , human androgen, and human progesterone receptors with high binding affinity scores. The obtained results confirmed that T. polium is a rich source of bioactive molecules with antioxidant and antitumor potential.
\end{abstract}


Keywords: Teucrium polium L.; HR-LCMS; phytochemistry; antioxidant; anticancer; Walker 256/B; MatLyLu; molecular docking

\section{Introduction}

Despite the arid and extra arid climate, the flora of Saudi Arabia is complex and contains more than 2285 species belonging to 855 genera [1,2]. In fact, $71.02 \%$ of these plants are herbs (1620 species), and many of them are classified as medicinal/aromatic ones. In the Hail region (northern central part of Saudi Arabia that extends between $250^{\circ} 29^{\prime} \mathrm{N}$ and $380^{\circ} 42^{\prime}$ E Page: 2), the vegetation is influenced by those of the Mediterranean countries in the mountains and the Saharo-Arabian and Irano-Turranean phyto-geographical regions in An Nafud sand seas, open plains, and wadis [3]. A large majority of these plants have aromatic and medicinal virtues for the aromas they give off, their essential oil, and their rich content in polyphenols. In Saudi Arabia, more than 1200 (over 50\%) of the total flowering plants (2250) are expected to be of medicinal importance.

The genus Teucrium includes more than 100 species and is largely distributed in Europe, North Africa, Asia, and especially in the Mediterranean region [4,5]. The Saudi Arabia flora comprises six Teucrium species: T. hijazicum Hedge \& R.A. King, T. leucocladum Boiss, T. oliverianum Ging. exBenth, T. polium L., T. popovii R.A. King, and T. yemense Defl [6]. Most plant extracts and their bioactive molecules have been shown to be scavengers of free radicals, which form the basis of their therapeutic potential [7-11]. Their antioxidant nature has been closely linked with the cancer-preventing property of a plant-derived compound due to the fact that the inhibition of oxidative stress reduces mutations and chromosomal aberrations, which initiate carcinogenesis [12]. The antioxidant and anticancer properties of T. polium have been extensively studied over the years [13,14], which are attributed to certain identified polyphenolic compounds identified.

In fact, Teucrium members have been shown to contain different classes of compounds such as fatty acid esters, diterpenes, monoterpenes, sesquiterpenes, flavonoids, and polyphenolics [15-17]. Flavonoids that have been isolated from T. polium species include cirsimaritin, cirsiliol, cirsilineol, 5-hydroxy-6,7,30,40-tetramethoxyflavone, salvigenin, apigenin 5-galloylglucoside, apigenin-7glucoside, vicenin-2-glucoside, and luteolin-7-glucoside [18-21]. In addition to their antioxidant activities, polyphenols have a wide range of biological activities [22-26]. Flavonoids also are known to protect the plant against ultraviolet radiation and possess anticancer [27,28], antioxidant, and anti-acetylcholinesterase activities [13,29-32]. It is also known that flavonoids possess antiviral, antifungal, and antibacterial properties [28,33]. To date, more than 134 bioactive compounds have been identified from different part of T. polium subspecies [34]. Teucrium species are used in folk medicine for treating many diseases such as abdominal pain, indigestion, common cold, diabetes, and urogenital diseases, and this plant has been reported to have hypolipidemic, antinociceptive, and anti-inflammatory effects $[18,21]$. It has been demonstrated that $T$. polium phytocompounds possess anti-diabetic, antiprofilative, pro-apoptotic, and anticancer activities [34-38].

The main objective of the present study was to investigate the phytochemical composition of T. polium methanolic extract using the HR-LCMS technique, the bioactive class of compounds (polyphenols, flavonoids, tannins ...), and its antioxidant properties using four test systems. The antitumor effect was tested against two malignant cell lines: MatLyLu and Walker 256/B. The computational approach was used to confirm the antioxidant and anticancer activities of the identified compounds targeting the human peroxiredoxin 5 enzyme and human androgen/progesterone receptors. 


\section{Materials and Methods}

\subsection{Plant Material Sampling and Extract Preparation}

The plant material was collected in October 2019 from a plant nursery in the Hail region (Saudi Arabia). The fresh aerial flowering parts (Figure 1) were dried at room temperature for ten days and then ground to a fine powder. Extracts were prepared according to Snoussi et al. [39]. Briefly, $40 \mathrm{~g}$ of the plant powder material were macerated in $400 \mathrm{~mL}$ of absolute methanol at room temperature for $48 \mathrm{~h}$ and re-extracted three times using the same procedure. Methanolic extracts were pooled, filtered, and the solvent was removed at $60{ }^{\circ} \mathrm{C}$ in the incubator chamber. The dried extracts were stored until further use. The yield was calculated using the following Formula (1):

$$
\text { Yield }(\%)=(\mathrm{W} 1 \times 100) / \mathrm{W} 2
$$

where W1 was the weight of extract after the evaporation of solvent, and W2 was the dry weight of the sample.

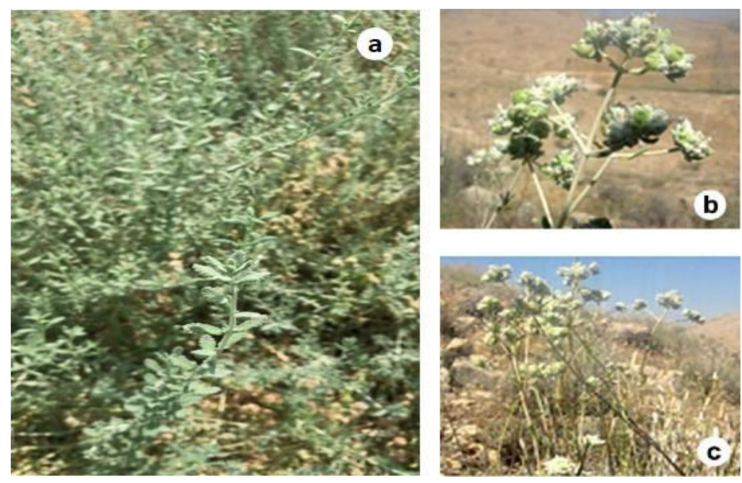

Figure 1. Vegetative growth (a), budding (b), and full bloom (c) of T. polium collected from Hail region.

\subsection{Phytochemical Profile of T. polium Extract}

\subsubsection{Phytochemical Analysis}

The methanolic extract from the aerial part of the felty germander was qualitatively tested for the presence of alkaloids, flavonoids, terpenoids, tannins, saponins, steroids, proteins, amino acids, and cardiac glucosides by following the protocol described by Sofowora [40], Trease and Evans [41], and Adetuyi and Popoola [42].

\subsubsection{Identification of Bioactive by High Resolution-Liquid Chromatography Mass Spectroscopy}

The phytochemical profile of the obtained crude methanolic extract from T. polium L. aerial parts was analyzed using a UHPLC-PDA-Detector 323 Mass Spectrophotometer (Agilent Technologies, Santa Clara, CA, USA). Compounds were identified via their mass spectra and their unique mass fragmentation patterns. Compound Discoverer 2.1, ChemSpider, and PubChem were used as the main tools for the identification of the phytochemical constituents [43].

\subsection{Biological Activities}

\subsubsection{Antioxidant Activities}

\section{DPPH Radical-Scavenging Activity}

The ability to scavenge the 1,1-diphenyl-2-picrylhydrazyl (DPPH) radical was calculated using the following Formula (2) as described by Chakraborty and Paulraj [44]: 


$$
\text { DPPH scavenging activity }(\%)=\left(\mathrm{A}_{0}-\mathrm{A}_{1}\right) / \mathrm{A}_{0} \times 100 \text {, }
$$

where $\mathrm{A}_{0}$ is the absorbance of the control and $\mathrm{A} 1$ is the absorbance of the sample. The antioxidant activity was expressed as $\mathrm{IC}_{50}(\mathrm{mg} / \mathrm{mL})$, which represented the extract concentrations scavenging $50 \%$ of DPPH radicals [45].

\section{ABTS Radical Scavenging Activity Assay}

The radical scavenging activity against ABTS (2,2'-azino-bis(3-ethylbenzothiazoline-6-sulfonic acid)) radical cations was measured using the method of Chakraborty and Paulraj [44]. The antiradical activity was expressed as $\mathrm{IC}_{50}(\mathrm{mg} / \mathrm{mL})$, which represented the extract concentrations scavenging $50 \%$ of ABTS radicals [45]. The inhibition percentage of ABTS radical was calculated using the following Formula (3):

$$
\text { ABTS scavenging activity }(\%)=\left(\mathrm{A}_{0}-\mathrm{A}_{1}\right) / \mathrm{A}_{0} \times 100,
$$

where $\mathrm{A}_{0}$ is the absorbance of the control, and $\mathrm{A} 1$ is the absorbance of the sample.

\section{Reducing Power Capability Assay}

The reducing power was determined using the method of Bi et al. (2013). The extract concentration providing 0.5 of absorbance $\left(\mathrm{IC}_{50}\right)$ was calculated from the graph of absorbance at $700 \mathrm{~nm}$ against sample concentration [46]. Ascorbic acid was used as a standard.

\section{$\beta$-carotene/Linoleic Acid Method}

The $\beta$-carotene method was carried out according to Ikram et al. [47]. Antioxidant activity (inhibition percentage, $\mathrm{PI} \%$ ) was evaluated using the following Formula (4):

$$
\mathrm{PI} \%=\left(\mathrm{A} \beta \text {-carotene } \mathrm{T}_{120} / \mathrm{A} \beta \text {-carotene } \mathrm{t}_{0}\right) \times 100,
$$

where $A \beta$-carotene $t_{0}$ and $A \beta$-carotene $T_{120}$ refer to the corresponding absorbance values of the test sample standard and control measured before and after incubation for $2 \mathrm{~h}$, respectively. All tests were performed in triplicate, and ascorbic acid (standard) was used for comparison.

\subsection{In Vitro Anticancer Assessment Using Malignant MatLyLu and Walker 256/B Cell Lines and MTT Assay}

Malignant MatLyLu (R33327) prostate cancer and Walker 256/B (W256) mammary gland cancer cells were used to test the in vitro anticancer activity of T. polium extract. These two cell lines were kindly provided by Prof. D. Chappard (Angers, France) to Dr. R. Badraoui (Sfax, Tunisia). MatLyLu and Walker 256/B malignant cells have a high osteolylic potential and are commonly used to induce osteosclerotic or osteolytic tumor lesions following the protocols previously described by Badraoui et al. [48,49].

MTT (3-[4จC-dimethylthiazole-2-yl]-2,5-diphenyltetrazolium bromide) assay was performed by the quantitative colorimetric method. Malignant Walker 256/B and MatLyLu $\left(5 \times 10^{2}\right.$ cells/well) were seeded on 96-well plates with or without T. polium extract. The effect on the viability of the used cells was realized by using the following growing concentrations: $0-200 \mu \mathrm{g} / \mathrm{mL}$. Pure ethanol was used as positive control. After 24 or $48 \mathrm{~h}$, cells were incubated with MTT solution for $2 \mathrm{~h}$. Then, the percentage of viability and inhibition was recorded by measuring the absorbance at $490 \mathrm{~nm}$.

\subsection{In Silico Study}

The antioxidant activity of T. polium methanolic extract was confirmed by molecular docking of the identified phytochemical compounds from T. polium methanolic extract into the active site of the human peroxiredoxin 5 enzyme, the human progesterone (PR) enzyme, and human androgen receptor. 
The intermolecular interactions between metabolites extracts and the active residues of peroxiredoxin 5 have been investigated using the AutoDock package [50]. The starting geometries of peroxiredoxin 5 and the original docked ligand benzoic acid were downloaded from the RCSB data bank web site: human peroxiredoxin 5 enzyme (PDB code 1HD2) [51], human progesterone (PDB code 4OAR) [46], human androgen receptor (PDB code 1E3G) [52].

The re-docking of the original ligand into the active site of the three tested target proteins are well reproduced with RMSD (root-mean-square deviation) values of $0.72,1.14$, and $0.651 \AA$, respectively, for peroxiredoxin 5 receptor, human progesterone receptor, and human androgen receptor. A stepwise molecular docking study was reported in previous study [48,53-55]. The docking calculations have been carried out using an Intel (R) Core (TM) i5-3770 CPU @ 3.40 GHz workstation.

\subsection{Statistical Analysis}

All measurements will be carried out in triplicate, and the results were presented as mean values $\pm \mathrm{SD}$ (standard deviations).

\section{Results}

\subsection{Phytochemical Composition}

High Resolution-Liquid Chromatography Mass Spectrometry (HR-LCMS) was carried out the chemical composition of the active extract. This technique was performed in the separation and identification of the phytoconstituents based on their retention time, database difference (library), experimental $\mathrm{m} / \mathrm{z}$, MS/MS fragments, metabolite class, and proposed compounds. MS data were provided in negative and positive ionization mode. The majority of the $\mathrm{m} / \mathrm{z}$ values in our extract were in the range from 133 to 742 . In fact, HR-LCMS analysis identified peptide-like proteins in the methanolic extract of T. polium.

A total of 20 small peptides (tripeptides), with molecular weights ranging from 319 to $537 \mathrm{~g} / \mathrm{mol}$, were tentatively identified by comparison of spectrum data of the extract with that of known compounds. Details of identified peptides are given in Table 1.

Table 1. Peptide-like proteins identified by the HR-LCMS technique in T. polium methanolic extract.

\begin{tabular}{cccccc}
\hline Small Peptides & Retention Time (mn) & Molecular Weight & Formula & {$[m / z]-$} & {$[m / z]+$} \\
\hline Asn Asn Asn & 0.945 & 360.1384 & $\mathrm{C}_{12} \mathrm{H}_{20} \mathrm{~N}_{6} \mathrm{O}_{7}$ & 341.1201 & - \\
His Phe Gln & 3.988 & 430.1976 & $\mathrm{C}_{20} \mathrm{H}_{26} \mathrm{~N}_{6} \mathrm{O}_{5}$ & 411.1797 & - \\
Gln His Phe & 4.05 & 430.1978 & $\mathrm{C}_{20} \mathrm{H}_{26} \mathrm{~N}_{6} \mathrm{O}_{5}$ & 447.1566 & - \\
Thr Leu Trp & 6.593 & 418.2222 & $\mathrm{C}_{21} \mathrm{H}_{30} \mathrm{~N}_{4} \mathrm{O}_{5}$ & 435.1808 & - \\
Arg Glu Trp & 7.029 & 489.2233 & $\mathrm{C}_{22} \mathrm{H}_{31} \mathrm{~N}_{7} \mathrm{O}_{6}$ & - & 512.2123 \\
Gln Phe Tyr & 7.241 & 456.202 & $\mathrm{C}_{23} \mathrm{H}_{28} \mathrm{~N}_{4} \mathrm{O}_{6}$ & 491.1714 & - \\
Trp Phe Trp & 7.837 & 537.2444 & $\mathrm{C}_{31} \mathrm{H}_{31} \mathrm{~N}_{5} \mathrm{O}_{4}$ & - & 373.1268 \\
Phe Tyr Gln & 8.417 & 456.2011 & $\mathrm{C}_{23} \mathrm{H}_{28} \mathrm{~N}_{4} \mathrm{O}_{6}$ & - & 183.1149 \\
Gln Phe Phe & 8.42 & 440.2065 & $\mathrm{C}_{23} \mathrm{H}_{28} \mathrm{~N}_{4} \mathrm{O}_{5}$ & - & 174.1475 \\
Gln Tyr Trp & 9.304 & 495.2108 & $\mathrm{C}_{25} \mathrm{H}_{29} \mathrm{~N}_{5} \mathrm{O}_{6}$ & - & 341.1374 \\
Thr Leu Ser & 9.441 & 319.1731 & $\mathrm{C}_{13} \mathrm{H}_{25} \mathrm{~N}_{3} \mathrm{O}_{6}$ & - & 342.1705 \\
Tyr Glu Trp & 9.572 & 496.1978 & $\mathrm{C}_{25} \mathrm{H}_{28} \mathrm{~N}_{4} \mathrm{O}_{7}$ & - & 95.0482 \\
Pro Trp Pro & 9.663 & 398.1964 & $\mathrm{C}_{21} \mathrm{H}_{26} \mathrm{~N}_{4} \mathrm{O}_{4}$ & - & 95.0479 \\
Trp Tyr Gln & 9.76 & 495.2113 & $\mathrm{C}_{25} \mathrm{H}_{29} \mathrm{~N}_{5} \mathrm{O}_{6}$ & - & 95.0486 \\
Asn His Met & 9.986 & 400.1527 & $\mathrm{C}_{15} \mathrm{H}_{24} \mathrm{~N}_{6} \mathrm{O}_{5} \mathrm{~S}$ & - & 95.0490 \\
Thr Trp Phe & 10.036 & 452.2084 & $\mathrm{C}_{24} \mathrm{H}_{28} \mathrm{~N}_{4} \mathrm{O}_{5}$ & - & 95.0499 \\
Lys His Cys & 10.229 & 386.1734 & $\mathrm{C}_{15} \mathrm{H}_{26} \mathrm{~N}_{6} \mathrm{O}_{4} \mathrm{~S}$ & - & 149.0968 \\
Lys Phe Cys & 10.598 & 396.1822 & $\mathrm{C}_{18} \mathrm{H}_{28} \mathrm{~N}_{4} \mathrm{O}_{4} \mathrm{~S}$ & - & 95.0491 \\
Trp Ser Tyr & 10.78 & 454.187 & $\mathrm{C}_{23} \mathrm{H}_{26} \mathrm{~N}_{4} \mathrm{O}_{6}$ & - & 95.0489 \\
Trp Pro Ile & 12.677 & 414.2271 & $\mathrm{C}_{22} \mathrm{H}_{30} \mathrm{~N}_{4} \mathrm{O}_{4}$ & - & 299.1620 \\
\hline
\end{tabular}


Figure 2 summarizes the most dominant chemical compounds identified in T. polium methanolic extract by using HR-LCMS techniques.

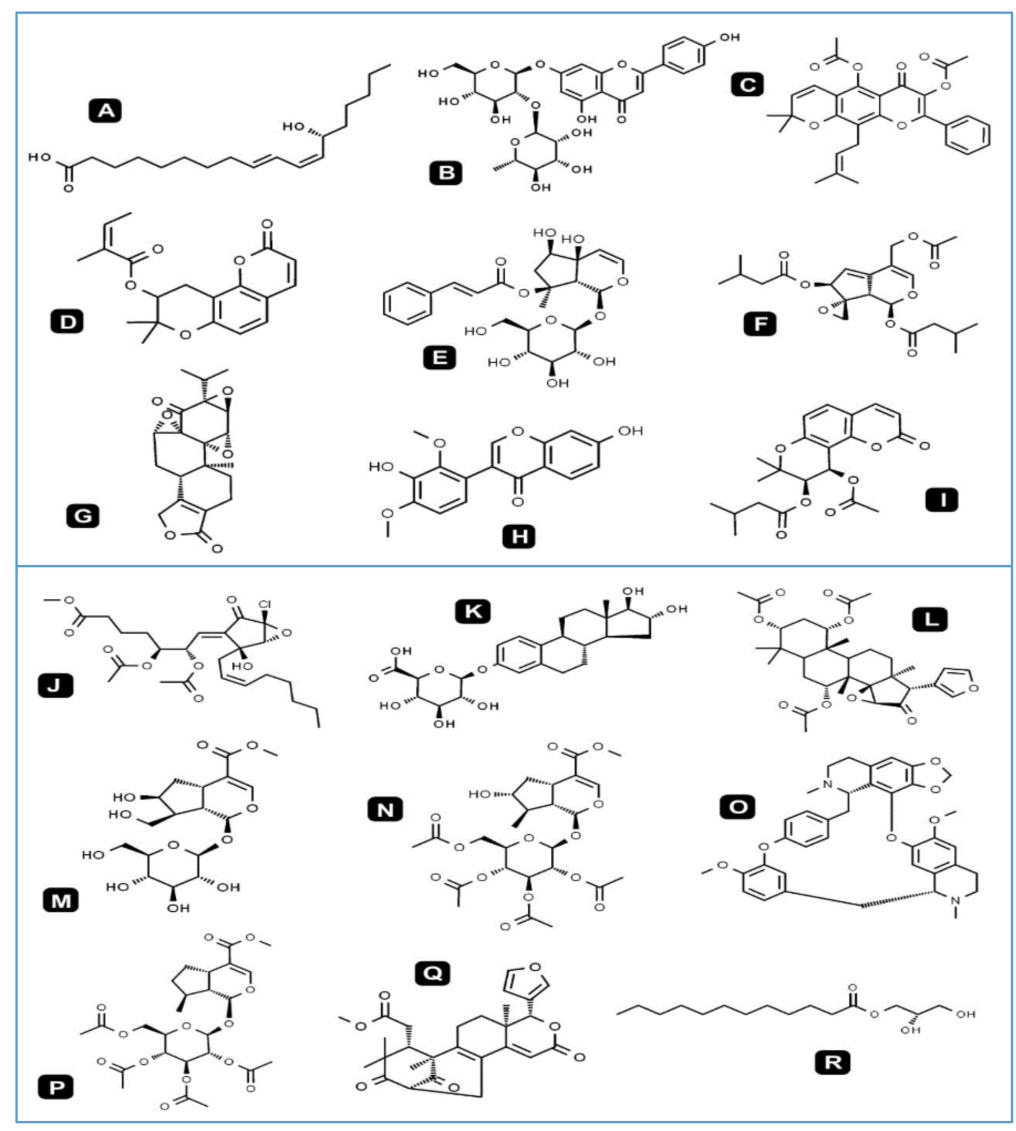

Figure 2. Chemical structures of the most dominant identified compounds in T. polium methanolic extract by using High Resolution-Liquid Chromatography Mass Spectrometry (HR-LCMS). (A). 13R-hydroxy-9E,11Z-octadecadienoic acid, (B). Rhoifolin, (C). Sericetin diacetate, (D). Selinidin, (E). Harpagoside, (F). Valtratum, (G). Triptonide, (H). Koparin 2'-Methyl Ether, (I). Dihydrosamidin (J). 10S,11R-Epoxy-punaglandin, (K). 4, 16alpha, 17beta-Estriol 3-(beta-D-glucuronide), (L). Khayanthone. (M). 10-Hydroxyloganin, (N). 7-Epiloganin tetraacetate, (O). Cepharanthine, (P). Deoxyloganin tetraacetate, (Q). Carapin-8 (9)-Ene, (R). 1-dodecanoyl-sn-glycerol.

Peptides of T. polium extract were composed of a majority of essential and non-essential amino acids distributed unevenly. Aromatic amino acids were predominant in $85 \%$ of the peptides with tryptophan (Trp) being the most commonly occurring amino acid (18.3\%). Tryptophan along with phenylalanine and tyrosine accounted for $43.3 \%$ of the total amino acids, followed by glutamine, asparagine, and histidine (25\%). Leucine, lysine, serine, glutamic acid, and cysteine together accounted for $16.7 \%$; and proline and threonine made up $10 \%$ of the total amino acids. Arginine, isoleucine, and methionine were amongst the least abundant amino acids, which accounted for $5 \%$ of the amino acids in the identified peptides. Aromatic rings were the most abundant side chains followed by amide side chains. Sulfur-containing side chains were rare in the identified peptides.

The repertoire of peptides of T. polium extract appeared to be more hydrophobic than hydrophilic from the amino acid composition, with hydrophobic amino acids accounting for $51.7 \%$ of the total amino acids. In addition, the majority of the peptides were composed solely of hydrophobic amino acids. Neutral amino acids made up of $88 \%$ of the amino acids followed by basic amino acids ( $8 \%)$. Consequently, 14 of the 20 peptides were neutral in nature. Glutamic acid was the only acidic amino acid detected and was present in two of the 20 peptides identified. As seen in Table 2 $(\mathrm{m} / \mathrm{z}$ values$)$, most of the peptides had a net positive charge as determined by spectrophotometric data. 
Table 2. Phytochemical composition of T. polium methanolic extract using the HR-LCMS technique.

\begin{tabular}{|c|c|c|c|c|c|c|}
\hline $\mathbf{N}^{\circ}$ & Identified Compound Name & $\begin{array}{c}\text { Class of } \\
\text { Compounds }\end{array}$ & RT [min] & Formula & $\begin{array}{c}{[\mathbf{M}+\mathbf{H}]^{+}} \\
(m / z)\end{array}$ & $\begin{array}{c}{[\mathbf{M}+\mathbf{H}]^{-}} \\
\quad(m / z)\end{array}$ \\
\hline 1 & 10-Hydroxyloganin & Isoprenoid & 0.945 & $\mathrm{C}_{17} \mathrm{H}_{26} \mathrm{O}_{11}$ & - & 406.1439 \\
\hline 2 & $\begin{array}{l}\text { 13R-Hydroxy-9E,11Z } \\
\text { octadecadienoic acid }\end{array}$ & Octadecanoid & 1.046 & $\mathrm{C}_{18} \mathrm{H}_{32} \mathrm{O}_{3}$ & 296.232 & - \\
\hline 3 & Bis (2-hydroxypropyl) amine & Amino Alcohol & 1.062 & $\mathrm{C}_{6} \mathrm{H}_{15} \mathrm{NO}_{2}$ & 133.1111 & - \\
\hline 4 & 9-Aminononanoic acid & $\begin{array}{l}\text { Amino Fatty } \\
\text { Acid }\end{array}$ & 1.447 & $\mathrm{C}_{9} \mathrm{H}_{19} \mathrm{NO}_{2}$ & 173.1401 & - \\
\hline 5 & 10-Aminodecanoic acid & $\begin{array}{l}\text { Amino Fatty } \\
\text { Acid }\end{array}$ & & $\mathrm{C}_{10} \mathrm{H}_{21} \mathrm{NO}_{2}$ & 187.156 & - \\
\hline 6 & 7-Epiloganin tetraacetate & Isoprenoid & 4.739 & $\mathrm{C}_{25} \mathrm{H}_{34} \mathrm{O}_{14}$ & - & 558.1987 \\
\hline 7 & $\begin{array}{l}\text { b-D-Glucopyranoside uronic acid, } \\
\text { 6-(3-oxobutyl)-2-naphthalenyl }\end{array}$ & $\begin{array}{l}\text { Organic Acid, } \\
\text { Phenol }\end{array}$ & 5.342 & $\mathrm{C}_{20} \mathrm{H}_{22} \mathrm{O}_{8}$ & - & 390.1284 \\
\hline 8 & Cepharanthine & Alkaloid & 5.948 & $\mathrm{C}_{37} \mathrm{H}_{38} \mathrm{~N}_{2} \mathrm{O}_{6}$ & & 606.2582 \\
\hline 9 & Rhoifolin & Flavonoid & 6.376 & $\mathrm{C}_{27} \mathrm{H}_{30} \mathrm{O}_{14}$ & 578.1634 & - \\
\hline 10 & Sericetin diacetate & Flavonol & 7.838 & $\mathrm{C}_{29} \mathrm{H}_{28} \mathrm{O}_{7}$ & 488.191 & - \\
\hline 11 & Troxerutin & Flavonol & 5.96 & $\mathrm{C}_{33} \mathrm{H}_{42} \mathrm{O}_{19}$ & - & 742.2379 \\
\hline 12 & Deoxyloganin tetraacetate & Isoprenoid & 6.319 & $\mathrm{C}_{25} \mathrm{H}_{34} \mathrm{O}_{13}$ & - & 542.2048 \\
\hline 13 & CMP-N-acetylneuraminic acid & Amino Sugar & 6.329 & $\mathrm{C}_{20} \mathrm{H}_{31} \mathrm{~N}_{4} \mathrm{O}_{16} \mathrm{P}$ & - & 614.1563 \\
\hline 14 & Carapin-8 (9)-Ene & Limonoid & 8.198 & $\mathrm{C}_{27} \mathrm{H}_{30} \mathrm{O}_{7}$ & - & 466.1996 \\
\hline 15 & Selinidin & $\begin{array}{l}\text { Coumarin } \\
\text { Derivative }\end{array}$ & 8.848 & $\mathrm{C}_{19} \mathrm{H}_{20} \mathrm{O}_{5}$ & 328.1303 & - \\
\hline 16 & Harpagoside & $\begin{array}{c}\text { Iridoid } \\
\text { Glycoside }\end{array}$ & 9.1 & $\mathrm{C}_{24} \mathrm{H}_{30} \mathrm{O}_{11}$ & 494.1782 & - \\
\hline 17 & 8-Epiiridodial glucoside tetraacetate & Isoprenoid & 9.126 & $\mathrm{C}_{24} \mathrm{H}_{34} \mathrm{O}_{11}$ & 498.2126 & - \\
\hline 18 & Larixol Acetate & - & 9.262 & $\mathrm{C}_{22} \mathrm{H}_{36} \mathrm{O}_{3}$ & 348.2635 & - \\
\hline 19 & Valtratum & Terpene & 9.525 & $\mathrm{C}_{22} \mathrm{H}_{30} \mathrm{O}_{8}$ & 422.1935 & - \\
\hline 20 & Triptonide & $\begin{array}{l}\text { Diterpene } \\
\text { triepoxide }\end{array}$ & 9.807 & $\mathrm{C}_{20} \mathrm{H}_{22} \mathrm{O}_{6}$ & 358.1419 & - \\
\hline 21 & Koparin 2'-Methyl Ether & Isoflavonoid & 10.036 & $\mathrm{C}_{17} \mathrm{H}_{14} \mathrm{O}_{6}$ & 314.0792 & - \\
\hline 22 & Dihydrosamidin & Coumarins & 10.779 & $\mathrm{C}_{21} \mathrm{H}_{24} \mathrm{O}_{7}$ & 388.1524 & - \\
\hline 23 & 10S,11R-Epoxy-punaglandin 4 & Eicosanoid & 11.022 & $\mathrm{C}_{25} \mathrm{H}_{35} \mathrm{ClO}_{9}$ & 514.1895 & - \\
\hline 24 & $\begin{array}{l}\text { 16Alpha,17beta-Estriol } \\
\text { 3-(beta-D-glucuronide) }\end{array}$ & $\begin{array}{l}\text { Steroidal } \\
\text { glycosides }\end{array}$ & 11.279 & $\mathrm{C}_{24} \mathrm{H}_{32} \mathrm{O}_{9}$ & 464.2051 & - \\
\hline 25 & 16-Hydroxy-4-carboxyretinoic Acid & Isoprenoid & 11.28 & $\mathrm{C}_{20} \mathrm{H}_{24} \mathrm{O}_{5}$ & 344.1621 & - \\
\hline 26 & Isotectorigenin, 7-Methyl ether & IsoFlavonoid & 12.149 & $\mathrm{C}_{18} \mathrm{H}_{16} \mathrm{O}_{6}$ & 328.0939 & - \\
\hline 27 & 3-hydroxy-3', 4'-Dimethoxyflavone & Flavonoid & 13.274 & $\mathrm{C}_{17} \mathrm{H}_{14} \mathrm{O}_{5}$ & 298.0829 & - \\
\hline 28 & Khayanthone & Limonoid & 18.427 & $\mathrm{C}_{32} \mathrm{H}_{42} \mathrm{O}_{9}$ & 570.2854 & - \\
\hline 29 & 1-Dodecanoyl-sn-glycerol & Glycerolipid & 20.37 & $\mathrm{C}_{14} \mathrm{H}_{22} \mathrm{~N}_{2} \mathrm{O}_{3}$ & - & 266.1651 \\
\hline
\end{tabular}

It is important to note that all compounds were first reported in this study for T. polium aerial parts methanolic extract analyzed with HR-LC/MS. The complete list of identified chemical bioactive compounds is summarized in Table 2.

\subsection{Phytoconstituents and Antioxidant Activities}

Phytochemical analysis showed the presence of diverse bioactive constituents such as saponins, cardiac glucosides, anthocyanin, terpenes, tannins, sterols, flavonols/flavanones, quinones, alkaloids, and coumarines. The results are summarized in Table 3.

The quantitative determination of phytochemical compounds specifies that the T. polium methanolic extract was rich in flavonoids (725 $\pm 0.001 \mathrm{mg} \mathrm{QE} / \mathrm{g}$ extract), tannins $(239 \pm 0.006 \mathrm{mg}$ QE/g extract), and phenols (72 $\pm 0.011 \mathrm{mg} \mathrm{QE} / \mathrm{g}$ extract). The obtained T. polium methanolic extract was evaluated for its antioxidant potentiality using four methods. The IC50 of each test was calculated and determined (Table 4). As it is shown, this extract had the strong radical inhibition of ABTS (IC50 $=0.042 \mathrm{mg} / \mathrm{mL}$ ) 
followed by DPPH $(\mathrm{IC} 50=0.087 \mathrm{mg} / \mathrm{mL}), \beta$-carotene/linoleic acid $(\mathrm{IC} 50=0.101 \mathrm{mg} / \mathrm{mL})$, and FRAP $(\mathrm{IC} 50=0.292 \mathrm{mg} / \mathrm{mL})$.

Table 3. Qualitative analysis of phytochemicals in methanolic extract of T. polium aerial parts.

\begin{tabular}{cccccccccccccc}
\hline $\begin{array}{c}\text { Phytochemical } \\
\text { Compounds }\end{array}$ & SAP & CAG & ANT & TER & FLAV & TAN & ST & QUI & COU & FLA & FAT & ALK \\
\hline T. polium extract & $(++)$ & $(++)$ & $(+)$ & $(++)$ & $(+)$ & $(+)$ & $(++)$ & $(+)$ & $(+)$ & $(+)$ & $(+)$ & $(+)$ \\
\hline
\end{tabular}

SAP: saponins, CAG: cardiac glucosides, ANT: anthocyanin, TER: terpenes, FLAV: flavonols and flavanones, TAN: tannins, ST: sterols, QUI: quinones, COU: coumarines, FL: flavonoids, FAT: fatty acids, ALK: alkaloids. $(+)$ : presence, $(-)$ : absent, $(++)$ : abundant.

Table 4. Antioxidant activities of T. polium + methanolic extract as compared to ascorbic acid and BHT.

\begin{tabular}{|c|c|c|c|}
\hline Test Systems & $\begin{array}{c}\text { T. polium } \\
\text { Methanolic Extract }\end{array}$ & (BHT) & (AA) \\
\hline \multicolumn{4}{|c|}{ Phytochemical Composition } \\
\hline $\begin{array}{l}\text { Total Flavonoids Content } \\
\text { (mg QE/g Extract) }\end{array}$ & $725 \pm 0.001$ & - & - \\
\hline $\begin{array}{l}\text { Total Tannins Content } \\
\text { (mg TAE/g Extract) }\end{array}$ & $239 \pm 0.006$ & - & - \\
\hline $\begin{array}{l}\text { Total Phenols Content } \\
\text { (mg GAE/g Extract) }\end{array}$ & $72 \pm 0.011$ & - & - \\
\hline \multicolumn{4}{|c|}{ Antioxidant Activities } \\
\hline DPPH IC $50(\mathrm{mg} / \mathrm{mL})$ & $0.087 \pm 0.001^{b}$ & $0.023 \pm 3 \times 10^{-4 a}$ & $0.022 \pm 5 \times 10^{-4 a}$ \\
\hline ABTS IC I0 $_{(\mathrm{mg} / \mathrm{mL})}$ & $0.042 \pm 0.014^{b}$ & $0.018 \pm 4 \times 10^{-4 \mathrm{a}}$ & $0.021 \pm 1 \times 10^{-3 a}$ \\
\hline$\beta$-carotene $\mathrm{IC}_{50}(\mathrm{mg} / \mathrm{mL})$ & $0.101 \pm 0.020^{c}$ & $0.042 \pm 3.5 \times 10^{-3 \mathrm{~b}}$ & $0.017 \pm 1 \times 10^{-3}$ \\
\hline FRAP IC $50(\mathrm{mg} / \mathrm{mL})$ & $0.292 \pm 0.042^{c}$ & $0.05 \pm 0.003^{a}$ & $0.09 \pm 0.007^{b}$ \\
\hline
\end{tabular}

BHT: butylated hydroxytoluene, AA: ascorbic acid. The letters $(\mathrm{a}-\mathrm{c})$ indicate a significant difference between the different antioxidant methods according to the Duncan test $(p<0.05)$.

\subsection{Anticancer Activities}

The anticancer effect of the T. polium extract was investigated by MTT assay on two malignant lineages: mammary gland carcinoma (Walker 256/B cells) and prostate cancer (MatLyLu). Both cell lines have high metastatic potential and are commonly used to induce bone metastases $[48,49]$. The cells were treated with the plant extract at different concentrations $0,50,100$, and $200 \mu \mathrm{g} / \mathrm{mL}$ for 24 or $48 \mathrm{~h}$.

Our findings, validated by the antiproliferative effects on malignant Walker 256/B and MatLyLu cells, suggested that the methanolic extract of T. polium possess an anticancer effect. Its phytochemical profile might act as chemopreventive agents against both Walker 256/B and MatLyLu. In fact, the extract suppressed the growth of the two malignant lines once compared with the controls $(0 \mu \mathrm{g} / \mathrm{mL})$ (Figure 3). The lowest viability was noticed with $200 \mu \mathrm{g} / \mathrm{mL}$ of T. polium extract for both cell lines. Overall, the effect was accentuated with the dose increase (dose-dependent), and it was more prominent after $48 \mathrm{~h}$ of treatment; the effect was dose and time-dependent.

\subsection{In Silico Study}

Overall, the in silico approach showed that for antioxidant and antitumor tests, the activity differs from one compound to another. These differences can be explained by the structural geometry of its basic skeleton, and to the presence of different specific substituted groups and heteroatoms in the studied bioactive compounds. In an attempt to rationalize the observed antioxidant activity of the identified molecules in T. polium extract, a molecular docking study has been carried out to determine their binding modes from one side and from another site of the active residues of human peroxiredoxin 5 . The results of the number of conventional intermolecular hydrogen bonding established between the docked compounds and active site residues of human peroxiredoxin 5 are summarized in Table 5 . 

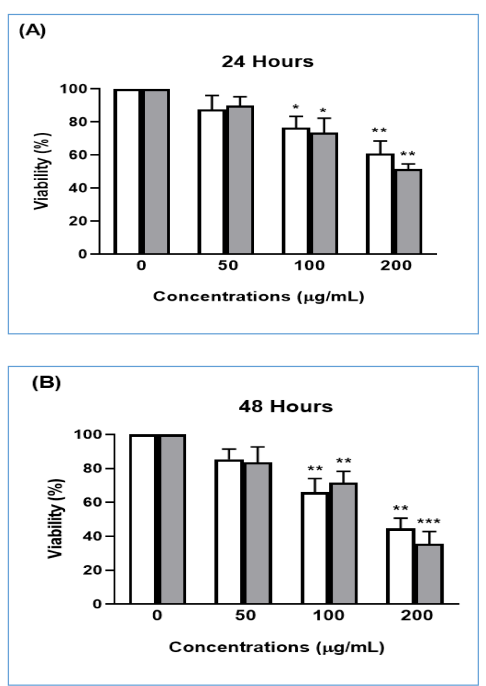

Figure 3. Anticancer effect of T. polium methanolic extract on malignant Walker 256/B mammary gland carcinoma cells (White) and MatLyLu prostate cancer cells (gray) in 24 (A) and $48 \mathrm{~h}$ (B). Legend: ${ }^{*} p<0.05,{ }^{* *} p<0.01,{ }^{* * *} p<0.001$.

Table 5. Docking binding energies, conventional hydrogen bonding, and the number of closest residues to the docked compounds into the active site of human peroxiredoxin 5 .

\begin{tabular}{|c|c|c|c|c|}
\hline Compound No. & Class of Compounds & $\begin{array}{c}\text { Free Binding } \\
\text { Energy } \\
\text { (kcal/mol) }\end{array}$ & $\begin{array}{l}\text { Conventional } \\
\text { H-Bonds (HBs) }\end{array}$ & $\begin{array}{l}\text { Number of Closest } \\
\text { Residues to the } \\
\text { Docked Ligand in the } \\
\text { Active Site }\end{array}$ \\
\hline 1 & Isoprenoid & -3.82 & 6 & 7 \\
\hline 2 & Octadecanoid & -5.35 & 6 & 5 \\
\hline 3 & Amino Alcohol & -2.15 & 3 & 2 \\
\hline 4 & Amino Fatty Acid & -4.54 & 6 & 6 \\
\hline 5 & Amino Fatty Acid & -4.60 & 5 & 5 \\
\hline 6 & Isoprenoid & -4.66 & 5 & 6 \\
\hline 7 & Organic Acid, Phenol & -5.05 & 3 & 6 \\
\hline 8 & Alkaloid & -5.07 & 1 & 6 \\
\hline 9 & Flavonoid & -5.09 & 8 & 11 \\
\hline 10 & Flavonol & -6.00 & 4 & 9 \\
\hline 11 & Flavonol & -2.01 & 8 & 9 \\
\hline 12 & Isoprenoid & -5.13 & 5 & 8 \\
\hline 13 & Amino Sugar & -8.06 & 5 & 6 \\
\hline 14 & Limonoid & -7.09 & 3 & 8 \\
\hline 15 & Coumarin Derivative & -5.94 & 3 & 7 \\
\hline 16 & Iridoid Glycoside & -4.78 & 6 & 6 \\
\hline 17 & Isoprenoid & -5.25 & 5 & 6 \\
\hline 18 & - & -6.03 & 2 & 7 \\
\hline 19 & Terpene & -5.17 & 5 & 8 \\
\hline 20 & diterpene triepoxide & -5.70 & 5 & 5 \\
\hline 21 & Isoflavonoid & -4.70 & 5 & 6 \\
\hline 22 & Coumarins & -5.37 & 4 & 6 \\
\hline 23 & Eicosanoid & -3.18 & 2 & 6 \\
\hline 24 & Steroidal Glycosides & -5.45 & 5 & 6 \\
\hline 25 & Isoprenoid & -5.15 & 3 & 7 \\
\hline 26 & IsoFlavonoid & - & - & - \\
\hline 27 & Flavonoid & -5.11 & 2 & 7 \\
\hline 28 & Limonoid & -6.14 & 4 & 8 \\
\hline 29 & Glycerolipid & -2.68 & 6 & 5 \\
\hline
\end{tabular}

All the complexes formed between the composition of T. polium methanolic extract (Table 5) and the active residues of Peroxiredoxin 5 have negative binding energies, which may explain the potent antioxidant activity of T. polium methanolic extract. The band energies of the stable complexes range 
from -8.06 to $-2.01 \mathrm{kcal} \mathrm{mol}^{-1}$. According to the molecular docking results, the amino sugar 13 showed the lowest binding energy $\left(-8.06 \mathrm{kcal} \mathrm{mol}^{-1}\right)$, and thus, the highest antioxidant activity was well fitted into the binding cavity of human peroxiredoxin 5 . This amino sugar forms five strong hydrogen bonding with amino acids ALA A42, THR A44, THR A147, GLY A46, and CYS A47 at distances of 2.04, $2.88,2.54,3.11$, and $2.81 \AA$, respectively (Figure 4 ), as well as a carbon hydrogen bond with PRO A45.
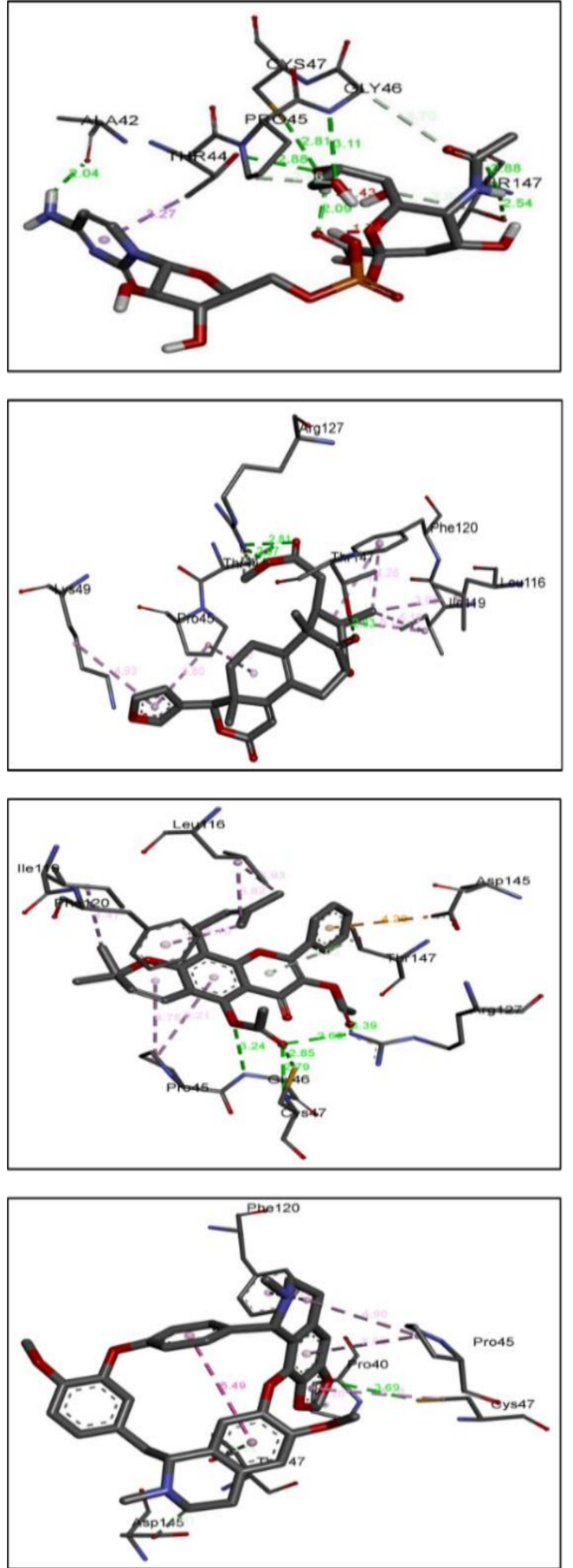
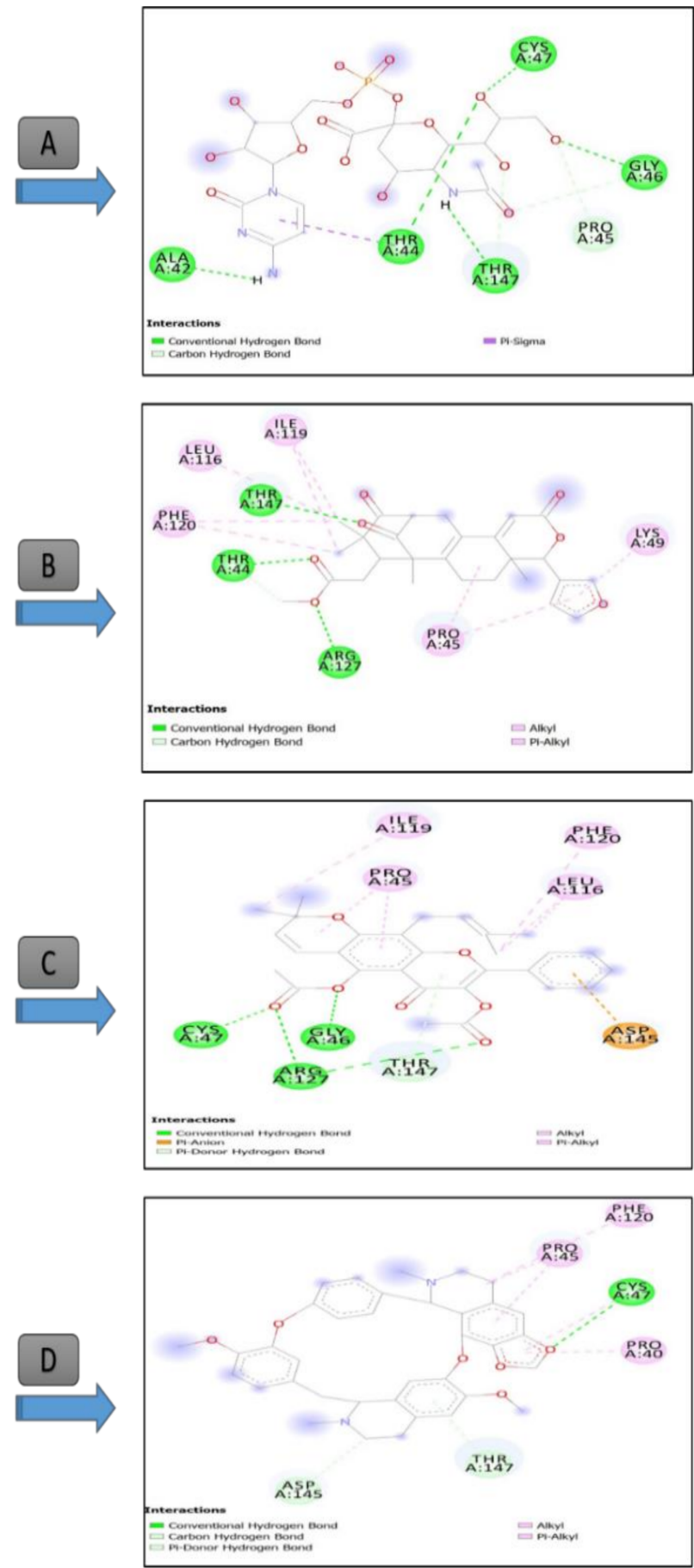

Figure 4. Three-dimensional (right) and two-dimensional (left) closest interactions between active site residues of peroxiredoxin 5 and some molecules belonging to different class compounds with the best score result. Legend: (A): Compound 13 (CMP-N-acetylneuraminic acid, Class: Amino Sugar), (B): Compound 14 (Carapin-8 (9)-Ene, Class: Limnoid), (C): Compound 10 (Sericetin diacetate, Class: Flavonol), and (D): Compound 8 (Cepharantine, Class: Alkaloid). 
It appears from the docking outputs in Table 5 that the antioxidant activity varies with subclass family. For instance, lemonoids $14\left(-7.09 \mathrm{kcal} \mathrm{mol}^{-1}\right)$ and $28\left(-6.14 \mathrm{kcal} \mathrm{mol}^{-1}\right)$ showed higher binding affinity compared with other subclasses (Table 5).

Table 6 summarized the calculated binding energies of the stable complexes ligand-progesterone, the number of conventional intermolecular hydrogen bonding established between the docked compounds, and the active site residues of progesterone.

Table 6. Docking binding energies, conventional hydrogen bonding, and the number of closest residues to the docked compounds into the active site of the human progesterone.

\begin{tabular}{|c|c|c|c|c|}
\hline No. & Class of Compounds & $\begin{array}{c}\text { Free Binding } \\
\text { Energy (kcal/mol) }\end{array}$ & $\begin{array}{l}\text { Conventional } \\
\text { H-Bonds (HBs) }\end{array}$ & $\begin{array}{c}\text { Number of Closest } \\
\text { Residues to the Docked } \\
\text { Ligand in the Active Site }\end{array}$ \\
\hline 1 & Isoprenoid & -7.10 & 8 & 8 \\
\hline 2 & Octadecanoid & -6.84 & 3 & 4 \\
\hline 3 & Amino Alcohol & -3.61 & 3 & 4 \\
\hline 4 & Amino Fatty Acid & -3.69 & 5 & 3 \\
\hline 5 & Amino Fatty Acid & -4.78 & 4 & 4 \\
\hline 6 & Isoprenoid & -7.83 & 3 & 7 \\
\hline 7 & Organic Acid, Phenol & -7.61 & 4 & 8 \\
\hline 8 & Alkaloid & -8.56 & 0 & 9 \\
\hline 9 & Flavonoid & -8.46 & 4 & 12 \\
\hline 10 & Flavonol & -9.48 & 0 & 5 \\
\hline 11 & Flavonol & -6.41 & 7 & 10 \\
\hline 12 & Isoprenoid & -7.97 & 3 & 9 \\
\hline 13 & Amino Sugar & -3.90 & 4 & 9 \\
\hline 14 & Limonoid & -10.45 & 0 & 10 \\
\hline 15 & Coumarin Derivative & -8.38 & 1 & 8 \\
\hline 16 & Iridoid Glycoside & -7.41 & 5 & 10 \\
\hline 17 & Isoprenoid & -8.07 & 2 & 10 \\
\hline 18 & - & -9.01 & 2 & 9 \\
\hline 19 & Terpene & -8.13 & 3 & 8 \\
\hline 20 & Diterpene triepoxide & -9.28 & 2 & 9 \\
\hline 21 & Isoflavonoid & -7.70 & 3 & 8 \\
\hline 22 & Coumarins & -8.78 & 2 & 12 \\
\hline 23 & Eicosanoid & -6.89 & 2 & 5 \\
\hline 24 & Steroidal Glycosides & -10.06 & 7 & 12 \\
\hline 25 & Isoprenoid & -8.63 & 4 & 11 \\
\hline 26 & IsoFlavonoid & -6.69 & 2 & 8 \\
\hline 27 & Flavonoid & -7.03 & 2 & 9 \\
\hline 28 & Limonoid & -10.83 & 2 & 11 \\
\hline 29 & Glycerolipid & -5.56 & 3 & 2 \\
\hline
\end{tabular}

All the complexes formed between the composition of T. polium methanolic extract (Table 6) and the active residues of progesterone showed negative binding energies, which may explain the observed anticancer activity of T. polium methanolic extract. The bond energies of the stable complexes range from -10.83 to $-3.61 \mathrm{kcal} \mathrm{mol}^{-1}$. According to molecular docking results, limonoids 28 and 14 showed the higher anticancer activity with lowest binding energies of -10.83 and $-10.45 \mathrm{kcal} \mathrm{mol}^{-1}$. The higher activity of 28 compared with 14 may be due to the extra intermolecular types of hydrogen bonding, and $\pi$-sulfur types appear in the former compared with the latter (Figure 5). Indeed, in the stable complex 28-progesterone, two strong hydrogen bonds were formed between 28 and the progesterone receptor. The first one is formed between the lone pair of oxygen atoms of the furan ring and the amino acid GLN A725 at a distance of $3.15 \AA$, and the second one at a distance of $3.06 \AA$ is established between the lone pair of an oxygen atom of cyclopentanone and VAL A760. $\pi$-Sulfor intermolecular interactions are formed between the $\pi$ bonds of furan ring and the amino acids MET A759 and MET A801 (Figure 5) of distances 5.44 and $5.29 \AA$, respectively. 

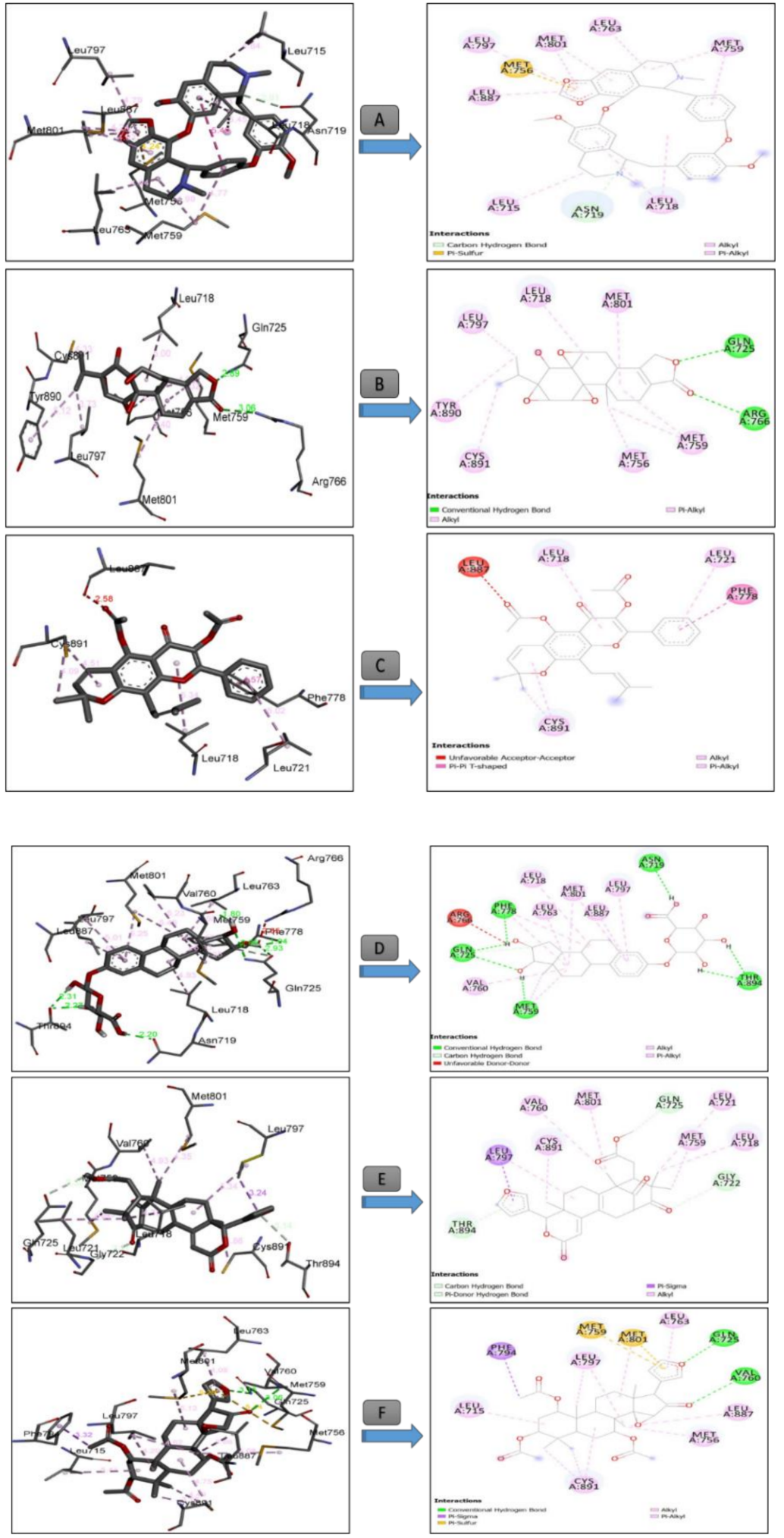

Figure 5. Three-dimensional (right) and two-dimensional (left) closest interactions between active site residues of the human progesterone receptor and some molecules belonging to different class compounds with the best score result. Legend: (A): Compound 8 (Cepharantine, Class: Alkaloid), (B): Compound 20 (Triptonide, Class: Diterpene triepoxide), (C): Compound 10 (Sericetin diacetate, Class: Flavonol), (D): Compound 24 (16alpha,17beta-Estriol 3-(beta-D-glucuronide, Class: Steroidal glycosides), (E): Compound 14 (Carapin-8 (9)-Ene, Class: Limnoid), (F): Compound 28 (Khayanthone, Class: Limnoid). 
Table 7 summarizes the calculated binding energies of the stable ligand-progesterone complexes, the number of conventional intermolecular hydrogen bonds established between the docked compounds, and the active site residues of the human androgen receptor. The complexes formed between the composition of T. polium methanolic extract (Table 7) and the active residues of androgen showed negative and positive binding energies. On one hand, the complexes that show negative binding energies may explain the anticancer activity of T. polium methanolic extract. On the other hand, the positive binding energies may indicate that the corresponding metabolites are not active; i.e., they have no anticancer activity. The bond energies of the stable complexes range -11.01 to $-3.49 \mathrm{kcal} \mathrm{mol}^{-1}$. According to the binding energies, compound 18 showed the higher anticancer activity with the lowest binding energy of $11.01 \mathrm{kcal} \mathrm{mol}^{-1}$ (Table 7 and Figure 6).
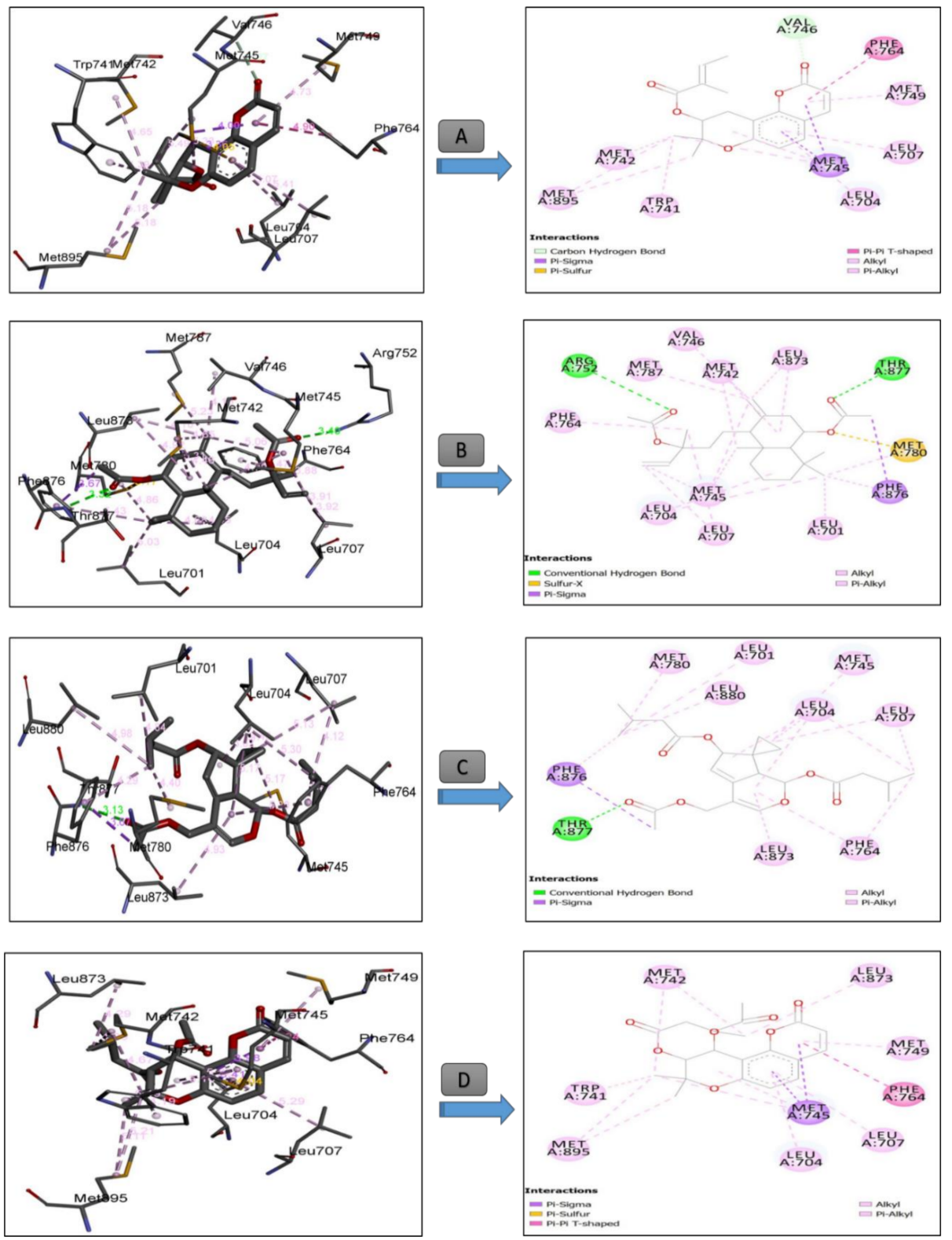

Figure 6. Three-dimensional (right) and 2D (left) closest interactions between the active site residues of the human androgen and some molecules belonging to different class compounds with the best score result. Legend: (A): Compound 15 (Selinidin, Class: coumarin derivative), (B): Compound 18 (larixol acetate), (C): Compound 19 (Valtratum, Class: Terpene) and (D): Compound 22 (dihydrosamidin, Class: coumarins). 
Table 7. Docking binding energies, conventional hydrogen bonding, and the number of closest residues to the docked compounds into the active site of the human androgen receptor.

\begin{tabular}{|c|c|c|c|c|}
\hline No. & Class of Compounds & $\begin{array}{c}\text { Free Binding } \\
\text { Energy (kcal/mol) }\end{array}$ & $\begin{array}{l}\text { Conventional } \\
\text { H-Bonds (HBs) }\end{array}$ & $\begin{array}{l}\text { Number of Closest } \\
\text { Residues to the Docked } \\
\text { Ligand in the Active Site }\end{array}$ \\
\hline 1 & Isoprenoid & -7.61 & 5 & 7 \\
\hline 2 & Octadecanoid & -8.01 & 3 & 4 \\
\hline 3 & Amino Alcohol & -3.51 & 3 & 3 \\
\hline 4 & Amino Fatty Acid & -5.74 & 5 & 3 \\
\hline 5 & Amino Fatty Acid & -6.13 & 5 & 3 \\
\hline 6 & Isoprenoid & -7.18 & 6 & 8 \\
\hline 7 & Organic Acid, Phenol & -8.31 & 2 & 7 \\
\hline 8 & Alkaloid & +134.65 & 0 & 5 \\
\hline 9 & Flavonoid & +19.33 & 1 & 10 \\
\hline 10 & Flavonol & -3.49 & 0 & 11 \\
\hline 11 & Flavonol & +29.13 & 4 & 11 \\
\hline 12 & Isoprenoid & -5.95 & 0 & 9 \\
\hline 13 & Amino Sugar & +2.64 & 4 & 8 \\
\hline 14 & Limonoid & -4.94 & 3 & 13 \\
\hline 15 & Coumarin Derivative & -9.70 & 0 & 9 \\
\hline 16 & Iridoid Glycoside & -8.07 & 3 & 9 \\
\hline 17 & Isoprenoid & -7.73 & 2 & 14 \\
\hline 18 & - & -11.01 & 2 & 13 \\
\hline 19 & Terpene & -9.66 & 1 & 10 \\
\hline 20 & Diterpene Triepoxide & -9.61 & 1 & 14 \\
\hline 21 & Isoflavonoid & -8.96 & 4 & 9 \\
\hline 22 & Coumarins & -9.81 & 0 & 9 \\
\hline 23 & Eicosanoid & -4.42 & 2 & 7 \\
\hline 24 & Steroidal Glycosides & +17.12 & 4 & 11 \\
\hline 25 & Isoprenoid & -4.96 & 3 & 12 \\
\hline 26 & IsoFlavonoid & -8.29 & 3 & 9 \\
\hline 27 & Flavonoid & -8.37 & 1 & 7 \\
\hline 28 & Limonoid & +9.39 & 0 & 7 \\
\hline 29 & Glycerolipid & -5.89 & 2 & 2 \\
\hline
\end{tabular}

The stability of the 18-androgen complex may refer to the strong interactions formed between 18 and amino acids of androgen (Figure 5). Indeed, two strong hydrogen bonds were formed between the acetyl groups of 18 and amino acids THR A877 and ARG 752 of the androgen receptor at distances of 3.32 and $3.40 \AA$, respectively (Figure 6). Furthermore, a strong sulfur- $X$ bond is formed between the oxygen atom of the acetyl group of 18 and the sulfur atom of the methylthiol moiety of MET A780 at a distance of $3.17 \AA$ (Figure 6).

\section{Discussion}

\subsection{Phytochemical Composition of T. polium Extract}

According to our result, terpenoids, also known as isoprenoids, are the most abundant compound class in the methanolic extract of T. polium aerial parts as defined by the HR-LCMS technique. Among the identified compounds (Table 1), many secondary metabolites with known antioxidants and anticancer activities belong to different classes of bioactive molecules, including isoprenoid, fatty acids, amino fatty acids, amino alcohols, glycerolipids, amino sugars, phenol, alkaloids, flavanol, small peptides, etc. $[55,56]$. It has been demonstrated that Liquid Chromatography Mass Spectrometry is a very sensitive method, which can identify many new compounds. Indeed, Aghakhani et al. [57] isolated twenty-two new flavonoid compounds that were first reported for Phlomis species. Our results are in agreement with previous studies that indicated that the Teucrium genus contains different classes of phytoconstituents such as monoterpenes, sesquiterpenes [58], polyphenols, flavonoids [59,60], and fatty acid esters $[61,62]$. Moreover, flavonoids are polyphenols that are detected in medicinal plants with a wide variety of biological activities [63]. Many previous studies have described the 
presence of various flavonoids such as apigenin, luteolin, rutin, cirsiliol, cirsimaritin, salvigenin, and eupatorin in the roots, aerial parts, and inflorescences of the plant [17,59-66]. Furthermore, one intermediate in the biosynthetic pathways of alkaloids, iridoid glycoside (Harpagoside), was also detected [60]. This compound has been detected in a wide variety of plants and in some animals. Furthermore, two iridoid glycosides, teucardoside and teuhircoside, from the hydrophilic fraction of T. polium var. pilosum and T. polium var. Alba were isolated [34]. Elmasri et al. [37] isolated iridoid and phenylethanol glycosides and a monoterpenoid from the areal part of T. polium. It was reported that $3^{\prime}, 4^{\prime}, 5$ trihydroxy-6,7-dimethoxy-flavone exhibited an inhibition of the biofilm-forming strain Staphylococcus aureus [37]. It was reported by Sharififar et al. [65] that the methanolic extract of the areal part of T. polium contains four major flavonoids where rutin and apigenin were found to be the most active fractions as radical scavengers. In 2018, Özer et al. [66] used the LC-MS/MS method to analyze compounds and to investigate the antioxidant activity of T. polium L. in decoction and infusion. Among the secondary metabolites, polyphenols represent an interesting class that have biological activities such as antioxidant and anticancer $[67,68]$. Moreover, flavonoids, another secondary metabolites class, are widely produced by plants to fight against biotic and abiotic aggression. It has been well demonstrated that this compounds exhibited antioxidant and anticancer activities $[69,70]$. The degree of polymerization and the differences arising from hydroxyl group substitutions makes this class of metabolites very large, with about 4000 different compounds [69].

Additionally, during our investigation, we identified 20 small peptide fragments with varying amino acid sequences via HR-LCMS analysis. Therefore, it was of interest to analyze the role of these peptides in the antioxidant and anticancer properties of the plant extracts. Peptides and peptide-like proteins have been found to be integral components of various plant species and have therapeutic applications due to their broad spectrum of biological activities such as antimicrobial, antioxidation, antihypertensive, immunomodulatory, and anticancer properties [71]. Although peptides from different plant species vary greatly with respect to amino acid composition and sequence, bioactive peptides possess certain common features such as small size, hydrophobicity, large percentage of aromatic amino acids, and amphiphatic nature [72].

\subsection{Antioxidant Activities}

The antioxidants of T. polium extracts have been widely studied [73-75]. For instance, using DPPH and $\beta$-carotene/linoleic acid assays, respectively, the petroleum ether (IC50 $=73.2 ; 9.2 \mu \mathrm{g} / \mathrm{mL}$ ), chloroform $(\mathrm{IC} 50=85.4 ; 5.1 \mu \mathrm{g} / \mathrm{mL})$, methanol $(\mathrm{IC} 50=20.1 ; 25.8 \mu \mathrm{g} / \mathrm{mL})$, and water $(\mathrm{IC} 50=40.6$; $19.2 \mu \mathrm{g} / \mathrm{mL}$ ) extracts of this plant which were collected from Kerman (Iran) showed strong antioxidant activity compared to our findings [65]. The aqueous extract of T. polium, collected from Israel, was evaluated for its antioxidant potentiality using various tests [76]. It inhibited superoxide radical $(\mathrm{IC} 50=12.0 \mu \mathrm{g} / \mathrm{mL})$, hydroxyl radical $(\mathrm{IC} 50=66.0 \mu \mathrm{g} / \mathrm{mL}), \beta$-carotene (inhibition percentage IP $=60 \%$ at $100 \mu \mathrm{g} / \mathrm{mL}$ ), iron-induced lipid peroxidation (IC50 $=7.0 \mu \mathrm{g} / \mathrm{mL}), 2,20$-azobis (2-amidinopropan) dihydrochloride (AAPH)-induced plasma oxidation (IP $=84 \%$ at $667 \mu \mathrm{g} / \mathrm{mL}$ ). It had also the capacity to bind iron (IC50 $=79.0 \mu \mathrm{g} / \mathrm{mL}$ ). At $1 \mathrm{mg} / \mathrm{mL}$, this aqueous extract had the ability to increase intracellular GSH (glutathione) levels in cultured HepG2 cells [76]. The 80\% ethanolic extract of T. polium, collected from Iran, was determined for its in vivo antiradical activity using 1,1-diphenyl-2-picrylhydrazyl $(\mathrm{DPPH})$ radical (78.6 and 90.7\%), total antioxidant power (23.6 and 37.5\%), and thiobarbituric acid reactive substances (24.7 and 31.8\%) in serum at 50 and $100 \mathrm{mg} / \mathrm{kg}$, respectively [77].

Our study showed the strong antioxidant capacity of the methanolic extract. This activity could not be related to the total phenolic, $(0.072 \mathrm{mg} \mathrm{GAE} / \mathrm{g}$ extract), flavonoid ( $0.725 \mathrm{mg} \mathrm{QE} / \mathrm{g}$ extract), or tannin contents $(0,239 \mathrm{mg}$ TAE/g extract), and the extract was analyzed by HR-LCMS in order to identify the major active compounds (Table 1 ). The results showed the presence of various chemical compounds, such as fatty acids, terpenes, alkaloids, coumarines, and flavonoids. These classes are already known by their antioxidant abilities $[78,79]$, and thus, they may explain the present activity. The analyzed peptides showed in Table 2 can also explain in part the antioxidant activity [80-82]. 
Furthermore, a previous study showed that the isoprenoid 10-hydroxyloganin had an insecticidal effect [83]. The limonoid khayanthone was detected in Punica granatum methanolic extract, which exhibited antioxidant potentiality [84]. The compounds 13R-hydroxy-9E,11Z-octadecadienoic, acid bis (2-hydroxypropyl) amine, 9-aminononanoic acid, and 10-aminodecanoic acid found in this plant, which belong to fatty acids, amino alcohols, and amino acid derivatives, were proved in the literature to have antiradical activity [85,86]. Cepharanthine is widely known in several clinical uses. It was used for the treatment of various diseases such as the inhibition of free radicals, radiation-induced leukopenia, venomous snakebites, etc. [87,88]. At $30 \mu \mathrm{g} / \mathrm{mL}$, cepharanthine had the ability of $94.6 \%$ inhibition on the peroxidation of linoleic acid [89]. It also exhibited activity using DPPH, ABTS, superoxide anion, ferrous ion chelating, total antioxidant activity, hydrogen peroxide, reducing power, and $N, N$-dimethyl-p-phenylenediamine dihydrochloride radicals scavenging [89]. Moreover, harpagoside inhibited free radicals at $1 \mathrm{mg} / \mathrm{mL}$ [90].

The relationship between the structure and activity of natural peptides with antioxidant properties has been vividly elucidated in a report by Zou et al. [91] where certain aspects of the chemical structure, namely the small size, presence of certain amino acids in large amounts, and hydrophobicity, are described as important factors that influence the antioxidant nature of peptides. Similar findings have been reported in several plant peptides such as those from Sphenostylis stenocarpa [92], hemp seed [93], phaseolin, bean [94], and Jatropha curcas [95] using several in vitro antioxidant evaluation systems such as diphenyl-1-picryhydradzyl (DPPH) and linoleic acid oxidation. In our study, many of the above-mentioned characteristics (small size, hydrophobicity, and high occurrence of aromatic amino acids) were seen in the peptides from T. polium, which further confirms the potential of the plant extract as a therapeutic agent.

\subsection{Anticancer Activities of T. polium Extract}

The anticancer effect of the Teucrium polium extract was investigated by MTT assay on two malignant lineages: mammary gland carcinoma (Walker 256/B cells) and prostate cancer (MatLyLu). Both cell lines have high metastatic potential and are commonly used to induce bone metastases [42,43]. The cells were treated with the plant extract at different concentrations 0, 50, 100 and $200 \mu \mathrm{g} / \mathrm{mL} \mathrm{for} 24$ or $48 \mathrm{~h}$.

As shown in Figure 3, T. polium extract seems to possess an anticancer effect. In fact, it inhibits the proliferation of both malignant Walker 256/B and MatLyLu cells in a concentration- and time-dependent manner. It has been previously reported that T. polium inhibited the proliferation of prostate cancer cells [96]. Similarly, several medicinal plant extracts inhibit the invasion, cancer evolution, and metastases. A recent study expected that in the near future, T. polium extract may be a novel anticancer agent [97]. This possibility is certainly related to the promising effects of the plant extract and could explain the ethno-pharmacological applications and the traditional use of T. polium. In fact, as shown in Tables 1 and 2, the plant methanolic extract exhibits a relevant and promising phytochemical composition following HR-LCMS assay. It includes, but is not limited to, flavonoid and isoflavonoid, isoprenoid, diterpene triepoxide (such as triptonide), and terpene (such as valtratum). All these chemical compounds possess pharmacological activities. Basically, these natural compounds, such as the triptonide, were effective in inhibiting tumorigenicity and tumor growth in a wide variety of cancers, including pancreatic cancer and thyroid induced metastases by activating the tumor-suppressive MAPK (mitogen-activated protein kinase) signaling pathway and via astrocyte elevated gene-1, respectively $[98,99]$. These phytochemical compounds might have better pharmacological properties together rather than separated. In fact, it has been reported that the effect of the whole plant is usually much better than that of its active phytochemical compounds [100].

Previous studies with T. polium extract reported potential anticancer effects by the inhibition of cell invasion and motility of human prostate cancer [96]. The mechanism includes E-caderin/catenin complex restoration. In this study, an anticancer effect has been revealed on the prostate MatLyLu cell line. Similarly, an in vivo study of prostate cancer and its lymph node, lung, and bone metastases complication 
due to MatLyLu cells could inhibit the invasion and metastatic potential via E-caderin/catenin complex restoration.

The effect of related plants showed efficient effects against breast and prostate cancer. In fact, extract from T. persicum was reported to inhibit PC-3 prostate cancer cells proliferation [101]. It has been demonstrated that both $T$. capitatum and T. creticum were effective against MCF-7 breast cancer cells [102]. Moreover, T. romasissimun and has an anticancer potential by inhibiting K562 proliferation [103]. Nevertheless, the reported IC50 values were different, and that could be related to the area from which the plant has been collected and/or the cancer cell types. However, it is well known that $T$. polium extract may also potentiate the apoptotic effects of some anticancer drugs such as doxorubicin and vinblastine on several cancer cell lines, including Saos-2, A431, SW480, and Skmel-3 [104]. Further preclinical investigations concerning the in vivo anticancer effects on Walker 256/B, MatLyLu, and other cancer types might be of potential interests to confirm the protective effect of $T$. polium and its possibility to contribute to the discovery of new drug products to treat cancer.

\subsection{In Silico Study}

Our molecular docking results with antioxidant human peroxiredoxin 5 were perfectly correlated with those of Eze et al. [105], confirming the same and highest binding pose of 1-(phenylsulphonyl)-N-propylpyrrolidine-2-carboxamide in the binding cavity of human peroxiredoxin 5 with a binding energy of $\left(-13.86 \mathrm{kcal} \mathrm{mol}^{-1}\right)$ and interactions with THR44, PRO40, PRO 45, GLY46, ARG127, THR147, and CYS A47 residues. Similarly, $\alpha$-tocopherol $\left(-7.2 \mathrm{kcal} \mathrm{mol}^{-1}\right)$ Cymbopogon citratus essential oil was perfectly fitted into the cavity of peroxiredoxin 5 establishing H-bonding with Arg 127(A) and non-covalent interactions with ASP A113, THR A147, LEU A116, SER A115, LEU A112, PRO A40, THR A44, GLY A46, CYS A47, PHE A120, and ASP A145. Additionally, caryophyllene oxide $\left(-7.1 \mathrm{kcal} \mathrm{mol}^{-1}\right)$ from the same essential oil was interacting with non-covalent interactions with PRO A40, THR A147, THR A44, PHE A120, PRO A45, LEU A116, and ILE A119 with amino of peroxiredoxin 5 amino acids residues, confirming therefore the high potency T. polium methanolic extract.

The obtained molecular docking interactions (Figure 5) of T. polium methanolic extract into the active site of the human progesterone enzyme were in good agreement with those reported by Acharya et al. [46]. In fact, these authors demonstrated that furanocoumarins, xanthotoxol, bergapten, angelicin, psoralen, and imperatonin are potent anti-breast cancer agents against progesterone. These molecules were buried into the active site of the human progesterone enzyme via the following molecular interactions: LEU718, GLN725, MET 759, LEU763, ARG766, PHE778 (xanthotoxol), GLN725, LEU721, LEU718, MET756, MET759, LEU763, ARG766, PHE778, MET801(bergapten), LEU718, LEU721, GLY722, GLN725, MET759, LEU763, LEU763, ARG766, PHE778 (angelicin), LEU718, LEU721, GLN725, MET756, MET759, LEU763, ARG766, PHE778, MET801 (psoralen) and LEU718, LEU721, GLY722, GLN725, MET756, LEU763, ARG768, PHE778, LEU797, MET801, and LEU887 (imperatonin).

Our results indicated that our selected compounds displaying the lowest binding energies share a higher number of common residues with the active sites of receptor 1E3G having the corresponding interacting residues, LEU 701, LEU 704, ASN 705, LEU 707, GLY 708, GLN 711, TRP 741, MET742, MET 745, VAL 746, MET 749, ARG 752, PHE 764, MET 780, MET787, LEU 873, PHE 876, THR 877, LEU 880, MET 895, and ILE 899. The docking results were well supported by those in vitro showing that T. polium methanolic extract can be a new potential resource of natural antioxidant and anticancer compounds.

\section{Conclusions}

The overall hydrophobic nature of peptides identified in T. polium methanolic extracts coupled with the small size of peptides and high concentration of aromatic amino acids ascertain its antioxidant and anticancer characteristics. Further in vivo studies are necessary to confirm the pharmacological properties of the identified molecules in vivo as promising antioxidant and antitumor agents. 
Author Contributions: Conceptualization, M.S., M.A. (Mousa Alreshidi), and V.D.F.; methodology, E.N., M.P., A.K., E.H.A., and S.E.; software, E.H.A., M.S.; validation, all authors; formal analysis, all authors; investigation, E.N., V.N.V., K.A., and A.K.; writing-original draft preparation, R.B., V.N.V., E.N., and S.E.; writing—review and editing, all authors; visualization, M.S. and V.D.F.; supervision, M.A. (Mousa Alreshidi), M.S.; project administration, M.A. (Mousa Alreshidi), M.S., and V.D.F.; funding acquisition, M.A. (Mousa Alreshidi). All authors have read and agreed to the published version of the manuscript.

Funding: This research has been funded by Scientific Research Deanship at University of Ha'il-Saudi Arabia through project number RG-191311.

Conflicts of Interest: The authors declare no conflict of interest.

\section{References}

1. White, F.; Leonard, J. Phytogeographical links between Africa and southwest Asia. Flora Veg. Mundi. 1991, 9, 229-246.

2. Alfarhan, A.A.H. Phytogeographical analysis of the floristic elements in Saudi Arabia. Pak. J. Biol. Sci. 1999, 2, 702-711.

3. El-Ghanim, W.M.; Hassan, L.M.; Galal, T.M.; Badr, A. Floristic composition and vegetation analysis in Hail region north of central Saudi Arabia. Saudi J. Biol. Sci. 2010, 17, 119-128. [CrossRef] [PubMed]

4. Mabberley, D.J. The Plant Book. In A Portable Dictionary of the Vascular Plants; Cambridge University Press: Cambridge, UK, 1997.

5. Bukhari, N.A.; Al-Otaibi, R.A.; Ibhrahim, M.M. Biodiversity characteristics of Teucrium polium species in Saudi Arabia. Saudi J. Biol. Sci. 2015, 22, 181-185. [CrossRef]

6. Collenette, S. Wildflowers of Saudi Arabia; National Commission for Wildlife Conservation and Development: Riyadh, Saudi Arabia, 1999.

7. Kadri, A.; Zarai, Z.; Ben Chobba, I.; Gharsallah, N.; Damak, M.; Bekir, A. Chemical composition and in vitro antioxidant activities of Thymelaea hirsuta L. essential oil from Tunisia. Afri. J. Biotechnol. 2011, 10, $2930-2935$.

8. Bakari, S.; Daoud, A.; Felhi, S.; Smaoui, S.; Gharsallah, N.; Kadri, A. Proximate analysis, mineral composition, phytochemical contents, antioxidant and antimicrobial activities and GC-MS investigation of various solvent extracts of cactus cladode. Food Sci. Technol. (Camp.) 2017, 27, 286-293. [CrossRef]

9. Felhi, S.; Baccouch, N.; Ben Salah, H.; Smaoui, S.; Allouche, N.; Gharsallah, N.; Kadri, A. Nutritional constituents, phytochemical profiles, in vitro antioxidant and antimicrobial properties and Gas chromatography-mass spectrometry (GC-MS) analysis of various solvent extracts from grape seeds (Vitis vinifera L.). Food Sci. Biotechnol. 2016, 25, 1537-1544. [CrossRef]

10. Gad-Elkareem, M.A.M.; Abdelgadir, E.H.; Badawy, O.M.; Kadri, A. Potential antidiabetic effect of ethanolic and aqueous-ethanolic extracts of Ricinus communis leaves on streptozotocin-induced diabetes in rats. Peer 2019, 7, e6441. [CrossRef]

11. Ben Mefteh, F.; Daoud, A.; Bouket, A.C.; Thissera, B.; Kadri, Y.; Cherif-Silini, H.; Eshelli, M.; Alenezi, F.N.; Vallat, A.; Oszako, T.; et al. Date palm trees root-derived endophytes as fungal cell factories for diverse bioactive metabolites. Int. J. Mol. Sci. 2018, 19, 1986. [CrossRef]

12. Jumeri; Kim, S.M. Anticancer and anticancer activities of enzymatic hydrolysates of solitary tunicate (Styela clava). Food Sci. Biotechnol. 2011, 20, 1075-1085. [CrossRef]

13. Khazaei, M.; Nematollahi-mahani, S.N.; Mokhtari, T.; Sheikhbahaei, F. Review on Teucrium polium biological activities and medical characteristics against different pathologic situations. J. Contemp. Med. Sci. 2018, 4, 1-6.

14. Bakari, S.; Ncir, M.; Felhi, S.; Hajlaoui, H.; Gharsallah, N.; Saoudi, M.; Kadri, A. Chemical composition and in vitro evaluation of total phenolic, flavonoid, and antioxidant properties of essential oil and solvent extract from the aerial parts of Teucrium polium grown in Tunisia. Food Sci. Biotechnol. 2015, 24, 1943-1949. [CrossRef]

15. Avula, B.; Manyam, R.B.; Bedir, E.; Khan, I.A. HPLC analysis of neo-clerodane diterpenoids from Teucrium chamaedrys. Pharmazie 2003, 58, 494-496.

16. Cozzani, S.; Muselli, A.; Desjobert, J.M.; Bernardini, A.F.; Tomi, F. Chemical composition of essential oil of Teucrium polium subsp. capitatum (L.) from Corsica. J. Essent. Oil Res. 2005, 10, 113-115.

17. Guetat, A.; Al-Ghamdi, F.A. Analysis of the essential oil of the germander (Teucrium polium L.) aerial parts from the northern region of Saudi Arabia. Int. J. Appl. Biol. Pharm. 2014, 5, 128-135.

18. Harborne, J.B.; Tomas, B.; Williams, G.A.; Gil, M.I. A chemotaxonomic study of flavonoids from European Teucrium species. Phytochemistry 1986, 25, 2811-2816. [CrossRef] 
19. Ali, E.M.; Razieh, Y. Hypoglycaemic effect of Teucrium polium: Studies with rat pancreatic islets. J. Ethnopharmacol. 2004, 95, 27-30.

20. Panovska, T.K.; Kulevanova, S.; Stefova, M. In vitro antioxidant activity of some Teucrium species (Lamiaceae). Acta Pharm. 2005, 55, 207-214.

21. Esmaeili, M.A.; Zohari, F.; Sadeghi, H. Antioxidant and Protective Effects of Major Flavonoids from Teucrium polium on $\beta$-Cell Destruction in a Model of Streptozotocin-Induced Diabetes. Planta Med. 2009, 75, 1418-1420. [CrossRef] [PubMed]

22. Bravo, L. Polyphenols: Chemistry, dietary sources, metabolism, and nutritional significance. Nutr. Rev. 1998, 56, 317-333. [CrossRef] [PubMed]

23. Benvenuti, S.; Pellati, F.; Melegari, M.; Bertelli, D. Polyphenols, anthocyanins, ascorbic acid, and radical scavenging activity of Rubus, Ribes, and Aronia. J. Food Sci. 2004, 69, FCT164-FCT169. [CrossRef]

24. Gunawardena, D.; Munch, G. Polyphenols in chronic diseases and their mechanisms of action. In Polyphenols in Human Health and Disease; Academic Press: Amsterdam, The Netherlands, 2014.

25. Pathak, S.; Kesavan, P.; Banerjee, A.; Banerjee, A.; Celep, G.S.; Bissi, L.; Marotta, F. Chapter 25: Metabolism of dietary polyphenols by human gut microbiota and their health benefits. In Polyphenols: Mechanism of Action in Human Health and Disease, 2nd ed.; Elsevier: London, UK, 2018; pp. 347-359.

26. Tijjani, H.; Zangoma, M.H.; Mohammed, Z.S.; Obidola, S.M.; Egbuna, C.; Abdulai, S.I. Polyphenols: Classifications, Biosynthesis and Bioactivities. In Functional Foods and Nutraceuticals; Egbuna, C., Dable Tupas, G., Eds.; Springer: Cham, Switzerland, 2020.

27. Brusselmans, K.; Vrolix, R.; Verhoeven, G.; Swinnen, J.V. Induction of cancer cell apoptosis by flavonoids is associated with their ability to inhibit fatty acid synthase activity. J. Biol. Chem. 2005, 280, 5636-5645. [CrossRef]

28. Jarial, R.; Thakur, S.; Sakinah, M.; Zularisam, A.W.; Sharad, A.; Kanwar, S.S.; Singh, L. Potent anticancer, antioxidant and antibacterial activities of isolated flavonoids from Asplenium nidus. J. King Saud Univ. Sci. 2018, 30, 185-192. [CrossRef]

29. Cook, N.C.; Samman, S. Flavonoids chemistry, metabolism, cardioprotective effects, and dietary sources. J. Nutr. Biochem. 1996, 7, 66-76. [CrossRef]

30. Hooper, L.; Kroon, P.A.; Rimm, E.B.; Cohn, J.S.; Harvey, I.; Le Cornu, K.A.; Ryder, J.J.; Hall, W.L.; Cassidy, A. Flavonoids, flavonoid-rich foods, and cardiovascular risk: A meta-analysis of randomized controlled trials. Am. J. Clin. Nutr. 2008, 88, 38-50. [CrossRef]

31. Cos, P.; Ying, L.; Calomme, M.; Hu, J.P.; Cimanga, K.; Van Poel, B.; Pieters, L.; Vlietinck, A.J.; Vanden Berghe, D. Structure-activity relationship and classification of flavonoids as inhibitors of xanthine oxidase and superoxide scavengers. J. Nat. Prod. 1998, 61,71-76. [CrossRef]

32. Golfakhrabadi, F.; Yousefbeyk, F.; Mirnezami, T.; Laghaei, P.; Hajimahmoodi, M.; Khanavi, M. Antioxidant and antiacetylcholinesterase activity of Teucrium hyrcanicum. Pharmacogn. Res. 2015, 7 (Suppl. 1), S15-S19.

33. Friedman, M. Overview of antibacterial, antitoxin, antiviral, and antifungal activities of tea flavonoids and teas. Mol. Nutr. Food Res. 2007, 51, 116-134. [CrossRef]

34. Bahramikia, S.; Yazdanparast, R. Phytochemistry and Medicinal Properties of Teucrium polium L. (Lamiaceae). Phytother. Res. 2012, 26, 1581-1593. [CrossRef]

35. Hasani-Ranjbar, S.; Nayebi, N.; Larijani, B.; Abdollahi, M. A systematic review of the Efficacy and Safety of Teucrium Species; from Anti-oxidant to Anti-diabetic Effects. Int. J. Pharmacol. 2010, 6, 315-325.

36. Stankovic, M.S.; Curcic, M.G.; Zizic, J.B.; Topuzovic, M.D.; Solujic, S.R.; Markovic, S.D. Teucrium Plant Species as Natural Sources of Novel Anticancer Compounds: Antiproliferative, Proapoptotic and Antioxidant Properties. Int. J. Mol. Sci. 2011, 12, 4190-4205. [CrossRef]

37. Elmasri, W.A.; Yang, T.; Tran, P.; Mohamed-Elamir Hegazy, F.; Hamood, A.N.; Mechref, Y.; Paré, P.W. Teucrium polium Phenylethanol and Iridoid Glycoside Characterization and Flavonoid Inhibition of Biofilm-Forming Staphylococcus aureus. J. Nat. Prod. 2014, 78, 2-9. [CrossRef]

38. Jaradat, N.A. Review of the taxonomy, ethnobotany, phytochemistry, phytotherapy and phytotoxicity of germander plant (Teucrium polium L.). Asian J. Pharm. Clin. Res. 2015, 8, 13-19.

39. Snoussi, M.; Trabelsi, N.; Dehmeni, A.; Benzekri, R.; Bouslama, L. Phytochemical analysis, antimicrobial and antioxidant activities of Allium roseum var. odoratissimum (Desf.) Coss. extracts. Ind. Crop. Prod. 2016, 89, 533-542. [CrossRef] 
40. Sofowora, A. Medicinal Plants and Traditional Medicine in West Africa; John Wiley and Sons: New York, NY, USA, 1982.

41. Trease, G.E.; Evans, W.C. Pharmacognosy, 11th ed.; Brailliar Tiridal Can Macmillian Publishers: London, UK, 1989.

42. Adetuyi, A.O.; Popoola, A.V. Extraction and dyes ability potential studies of the colourant in Zanthoxylum zanthoxyloides plant on cotton fabric. J. Sci. Eng. Technol. 2001, 8, 3291-3299.

43. Adnan, M.; Patel, M.; Deshpande, S.; Alreshidi, M.; Siddiqui, A.J.; Reddy, M.N.; Noumi, E.; De Feo, V. Effect of Adiantum philippense extract on biofilm formation, adhesion with its antibacterial activities against foodborne pathogens, and characterization of bioactive metabolites: An in vitro-in silico approach. Front. Microbiol. 2020. [CrossRef]

44. Chakraborty, K.; Paulraj, R. Sesquiterpenoids with free-radical-scavenging properties from marine macroalga Ulva fasciata Delile. Food Chem. 2010, 122, 31-41. [CrossRef]

45. Nishaa, S.; Vishnupriya, M.; Sasikumar, J.M.; Christabel, H.P.; Gopalakrishnan, V.K. Antioxidant activity of ethanolic extract of Maranta Arundinacea L. tuberous rhizomes. Asian J. Pharm. Clin. Res. 2012, 5, 85-88.

46. Barros, L.; João, F.M.; Queirós, B.; Ferreira, I.C.; Baptista, P. Total phenols, ascorbic acid, $\beta$-carotene and lycopene in Portuguese wild edible mushrooms and their antioxidant activities. Food Chem. 2007, 103, 413-419. [CrossRef]

47. Ikram, E.H.K.; Eng, K.H.; Jalil, A.M.M.; Ismail, A.; Idris, S.; Azlan, A.; Nazri, H.S.M.; Diton, N.A.M.; Mokhtar, R.A.M. Antioxidant capacity and total phenolic content of Malaysian underutilized fruits. J. Food Compos. Anal. 2009, 22, 388-393. [CrossRef]

48. Badraoui, R.; Rebai, T. Effect of malignant ascites on antioxidative potency of two tumoral cells-induced bone metastases: Walker 256/B and MatLyLu. Exp. Toxicol. Pathol. 2012, 64, 65-68. [CrossRef]

49. Badraoui, R.; Boubakri, M.; Bedbabiss, M.; Ben-Nasr, H.; Rebai, T. Walker 256/B malignant breast cancer cells enhance femur angiogenesis and disrupt hematological parameters in rats. Tumor Biol. 2014, 35, 3663-3670. [CrossRef]

50. Morris, G.M.; Huey, R.; Lindstrom, W.; Sanner, M.F.; Belew, R.K.; Goodsell, D.S.; Olson, A.J. AutoDock4 and AutoDockTools4: Automated docking with selective receptor flexibility. J. Comput. Chem. 2009, 30, 2785-2791. [CrossRef]

51. Knoops, B.; Goemaere, J.; Van der Eecken, V.; Declercq, J.P. Peroxiredoxin 5: Structure, mechanism, and function of the mammalian atypical 2-Cys peroxiredoxin. Antioxid. Redox Signal. 2011, 15, 817-829. [CrossRef] [PubMed]

52. Acharya, R.; Chacko, S.; Bose, P.; Lapenna, A.; Pattanayak, S.P. Structure Based Multitargeted Molecular Docking Analysis of Selected Furanocoumarins against Breast Cancer. Sci. Rep. 2019, 9, 15743. [CrossRef]

53. Singh, A.N.; Baruah, M.M.; Sharma, N. Structure based docking studies towards exploring potential antiandrogen activity of selected phytochemicals against prostate Cancer. Sci. Rep. 2017, 7, 1955. [CrossRef]

54. Othman, I.M.; Gad-Elkareem, M.A.; Snoussi, M.; Aouadi, K.; Kadri, A. Novel fused pyridine derivatives containing pyrimidine moiety as prospective tyrosyl-tRNA synthetase inhibitors: Design, synthesis, pharmacokinetics and molecular docking studies. J. Mol. Struct. 2020, 1219, 128651. [CrossRef]

55. Tonthubthimthong, P.; Chuaprasert, S.; Douglas, P.; Luewisuttichat, W. Supercritical $\mathrm{CO}_{2}$ extraction of nimbin from neem seeds an experimental study. J. Food Eng. 2001, 47, 289-293. [CrossRef]

56. Dandekar, A.; Mendez, R.; Zhang, K. Cross Talk between ER Stress, Oxidative Stress, and Inflammation in Health and Disease. In Stress Responses. Methods in Molecular Biology; Oslowski, C., Ed.; Humana Press: New York, NY, USA, 2015; Volume 1292, pp. 205-214.

57. Aghakhani, F.; Kharazina, N.; Gooini, Z.L. Flavonoid constituents of Phlomis (Lamiaceae) species using liquid chromatography mass spectrometry. Phytochem. Anal. 2017. [CrossRef]

58. Bruno, M.; De la Torre, M.C.; Rodríguez, B.; Omar, A.A. Guaiane sesquiterpenes from Teucrium leucocladum. Phytochemistry 1993, 34, 245-247. [CrossRef]

59. Kawashty, S.A.; Gamal El-Dinb, E.M.; Saleh, N.A.M. The flavonoid chemosystematics of two Teucrium species from Southern Sinai, Egypt. Biochem. Syst. Ecol. 1999, 27, 657-660. [CrossRef]

60. Rizk, A.M.; Hammouda, F.M.; Rimpler, H.; Kamel, A. Iridoids and flavonoids of Teucrium polium herb. Planta Med. 1986, 2, 87-88. [CrossRef]

61. Boulila, A.; Béjaoui, A.; Messaoud, C.; Boussaid, M. Variation of volatiles in Tunisian populations of Teucrium polium L. (Lamiaceae). Chem. Biodivers. 2008, 5, 1385-1400. [CrossRef] 
62. Hachicha, S.F.; Barrek, S.; Skanji, T.; Zarrouk, H.; Ghrabi, Z.G. Fatty acid, tocopherol, and sterol content of three Teucrium species from Tunisia. Chem. Nat. Comp. 2009, 45, 304-308. [CrossRef]

63. Carreiras, M.C.; Rodriguez, B.; Piozzi, S.; Savona, G.; Torres, M.R.; Parales, A. A chlorine-containing and two 17b-neo-clerodane diterpenoids from Teucrium polium subsp. vincentinum. Phytochemistry 1989, 28, 1453-1461. [CrossRef]

64. Litvinenko, V.I.; Zoz, I.G.; Sokolov, V.S. Chemotaxonomische Untersuchungen zur Unterfamilie Ajugoideae Benth. Der Lamiaceae Lindley. Planta Med. 1970, 3, 243-253. [CrossRef]

65. Sharififar, F.; Dehghn-Nudeh, G.; Mirtajaldinic, M. Major flavonoids with antioxidant activity from Teucrium polium L. Food Chem. 2009, 11, 885-888. [CrossRef]

66. Özer, Z.; Kiliç, T.; Çarikçi, S.; Yilmaz, H. Investigation of phenolic compounds and antioxidant activity of Teucrium polium L. decoction and infusion. J. BAUN Inst. Sci. Technol. 2018, 20, 212-218.

67. Droge, W. Free radicals in the physiological control of cell function. Physiol. Rev. 2002, 82, 47-95. [CrossRef]

68. Wanasundara, P.K.J.P.D.; Shahidi, F. Antioxidants: Science, technology, and applications. In Bailey's Industrial Oil and Fat Products, 6th ed.; Shahidi, F., Ed.; John Wiley \& Sons, Inc.: Hoboken, NJ, USA, 2005; pp. 431-489.

69. Lee, J.S.; Kim, D.H.; Liu, K.H.; Oh, T.K.; Lee, C.H. Identification of flavonoids using liquid chromatography with electrospray ionization and ion trap tandem mass spectrometry with an MS/MS library. Rapid Commun. Mass Spectrom. 2005, 19, 3539-3548. [CrossRef]

70. Chen, H.J.; Inbaraj, B.S.; Chen, B.H. Determination of phenolic acids and flavonoids in Taraxacum formosanum Kitam by liquid chromatography-tandem mass spectrometry coupled with a postcolumn derivatization technique. Int. J. Mol. Sci. 2012, 13, 260-285. [CrossRef]

71. Sánchez, A.; Vázquez, A. Bioactive peptides: A review. Food Qual. Safe 2017, 1, 29-46. [CrossRef]

72. Moller, N.P.; Scholz-Ahrens, K.E.; Roos, N.; Schrezenmeir, J. Bioactive peptides and proteins from foods: Indication for health effects. Eur. J. Nutr. 2008, 47, 171-182. [CrossRef]

73. Stankovic, M.S.; Niciforovic, N.; Mihailovic, V.; Topuzovic, M.; Solujic, S. Antioxidant activity, total phenolic content and flavonoid concentrations of different plant parts of Teucrium polium L. subsp. polium. Acta Soc. Bot. Pol. 2012, 133, 117-122. [CrossRef]

74. Tepe, B.; Degerli, S.; Arslan, S.; Malatyali, E.; Sarikurkcu, C. Determination of chemical profile, antioxidant, DNA damage protection and antiamoebic activities of Teucrium polium and Stachys iberica. Fitoterapia 2011, 82, 237-246. [CrossRef]

75. De Marino, S.; Festa, C.; Zollo, F.; Incollingo, F.; Raimo, G.; Evangelista, G.; Iorizzi, M. Antioxidant activity of phenolic and phenylethanoid glycosides from Teucrium polium L. Food Chem. 2012, 133, 21-28. [CrossRef]

76. Ljubuncic, P.; Dakwar, S.; Portnaya, I.; Cogan, U.; Azaizeh, H.; Bomzon, A. Aqueous extracts of Teucrium polium possess remarkable antioxidant activity in vitro. Evid. Based Complement Altern. Med. 2006, 3, 329-338. [CrossRef]

77. Hasani, P.; Yasa, N.; Vosough-Ghanbari, S.; Mohammadirad, A.; Dehghan, G.; Abdollahi, M. In vivo antioxidant potential of Teucrium polium, as compared to $\alpha$-tocopherol. Acta Pharm. 2007, 57, 123-129. [CrossRef]

78. Wang, R.; Zhou, J.; Shi, G.; Liu, Y.; Yu, D. Aporphine and phenanthrene alkaloids with antioxidant activity from the roots of Stephania tetrandra. Fitoterapia 2020, 143, 104551. [CrossRef]

79. Yu, J.; Wang, L.; Walzem, R.L.; Miller, E.G.; Pike, L.M.; Patil, B.S. Antioxidant activity of citrus limonoids, flavonoids, and coumarins. J. Agric. Food Chem. 2005, 53, 2009-2014. [CrossRef]

80. Kawashima, K.; Itoh, H.; Miyoshi, M.; Chibata, I. Antioxidant properties of branched-chain amino acid derivatives. Chem. Pharm. Bull. 1979, 27, 1912-1916. [CrossRef] [PubMed]

81. Wong, F.C.; Xiao, J.; Wang, S.; Ee, K.Y.; Chai, T.T. Advances on the antioxidant peptides from edible plant sources. Trends Food Sci. Technol. 2020, 99, 44-57. [CrossRef]

82. Xie, Z.; Huang, J.; Xu, X.; Jin, Z. Antioxidant activity of peptides isolated from alfalfa leaf protein hydrolysate. Food Chem. 2008, 111, 370-376. [CrossRef]

83. Tzakou, O.; Mylonas, P.; Vagias, C.; Petrakis, P.V. Iridoid glucosides with insecticidal activity from Galium melanantherum. Z. Nat. 2007, 62, 597-602. [CrossRef]

84. Mestry, S.N.; Gawali, N.B.; Pai, S.A.; Gursahani, M.S.; Dhodi, J.B.; Munshi, R.; Juvekar, A.R. Punica granatum improves renal function in gentamicin-induced nephropathy in rats via attenuation of oxidative stress. J. Ayurveda Integr. Med. 2020, 11, 16-23. [CrossRef] 
85. Siow, H.L.; Gan, C.Y. Extraction of antioxidative and antihypertensive bioactive peptides from Parkia speciosa seeds. Food Chem. 2013, 141, 4-3435. [CrossRef]

86. Tie, H.M.; Wu, P.; Jiang, W.D.; Liu, Y.; Kuang, S.Y.; Zeng, Y.Y.; Jiang, J.; Tang, L.; Zhou, X.Q.; Feng, L. Dietary nucleotides supplementation affect the physicochemical properties, amino acid and fatty acid constituents, apoptosis and antioxidant mechanisms in grass carp (Ctenopharyngodon idellus) muscle. Aquaculture 2019, 502, 312-325. [CrossRef]

87. Rogosnitzky, M.; Danks, R. Therapeutic potential of the biscoclaurine alkaloid, cepharanthine, for a range of clinical conditions. Pharmacol. Rep. 2011, 63, 337-347. [CrossRef]

88. Kusaka, J.; Hagiwara, S.; Hasegawa, A.; Kudo, K.; Koga, H.; Noguchi, T. Cepharanthine Improves Renal Ischemia-Reperfusion Injury in Rats. J. Surg. Res. 2011, 171, 212-217. [CrossRef] [PubMed]

89. Gülçin, İ.; Elias, R.; Gepdiremen, A.; Chea, A.; Topal, F. Antioxidant activity of bisbenzylisoquinoline alkaloids from Stephania rotunda: Cepharanthine and fangchinoline. J. Enzym. Inhib. Med. Chem. 2010, 25, 44-53. [CrossRef]

90. Kaszkin, M.; Beck, K.; Koch, E.; Erdelmeier, C.; Kusch, S.; Pfeilschifter, J.; Loew, D. Downregulation of iNOS expression in rat mesangial cells by special extracts of Harpagophytum procumbens derives from harpagoside-dependent and independent effects. Phytomedicine 2004, 11, 585-595. [CrossRef]

91. Zou, T.B.; He, T.P.; Li, H.B.; Tang, H.W.; Xia, E.Q. The structure-activity relationship of the antioxidant peptides from natural proteins. Molecules 2016, 21, 72. [CrossRef]

92. Ajibola, C.F.; Fashakin, J.B.; Fagbemi, T.N.; Aluko, R.E. Effect of peptide size on antioxidant properties of African yam bean seed (Sphenostylis stenocarpa) protein hydrolysate fractions. Int. J. Mol. Sci. 2011, 12, 6685-6702. [CrossRef]

93. Girgih, A.T.; He, R.; Malomo, S.; Offengenden, M.; Wu, J.P.; Aluko, R.E. Structural and functional characterization of hemp seed (Cannabis sativa L.) protein-derived antioxidant and antihypertensive peptides. J. Funct. Foods 2014, 6, 384-394. [CrossRef]

94. Carrasco-Castilla, J.; Hernandez-Alvarez, A.J.; JimenezMartinez, C.; Alaiz, M.; Girón-Calle, J.; Vioque, J.; Dávila-Ortiz, G. Antioxidant and metal chelating activities of peptide fractions from phaseolin and bean protein hydrolysates. Food Chem. 2012, 135, 1789-1795. [CrossRef]

95. Marrufo-Estrada, D.M.; Segura-Campos, M.R.; Chel-Guerrero, L.A.; Betancur-Ancona, D.A. Defatted Jatropha curcas flour and protein isolate as materials for protein hydrolysates with biological activity. Food Chem. 2013, 138, 77-83. [CrossRef]

96. Kandouz, M.; Alachkar, A.; Zhang, L.; Dekhil, H.; Chehna, F.; Yasmeen, A.; Al Moustafa, A.-E. Teucrium polium plant extract inhibits cell invasion and motility of human prostate cancer cells via the restoration of the E-cadherin/catenin complex. J. Ethnopharmacol. 2010, 129, 410-415. [CrossRef] [PubMed]

97. Emami Zeydi, A. Teucrium polium plant extract as a novel anticancer agent in the near future: Is it possible? Indian J. Cancer 2016, 53, 66. [CrossRef]

98. Zhang, B.; Meng, M.; Xiang, S.; Cao, Z.; Xu, X.; Zhao, Z.; Zhang, T.; Chen, B.; Yang, P.; Li, Y.; et al. Selective activation of tumor-suppressive MAPKP signaling pathway by triptonide effectively inhibits pancreatic cancer cell tumorigenicity and tumor growth. Biochem. Pharmacol. 2019, 166, 70-81. [CrossRef]

99. Fu, L.; Niu, X.; Jin, R.; Xu, F.; Ding, J.; Zhang, L.; Huang, Z. Triptonide inhibits metastasis potential of thyroid cancer cells via astrocyte elevated gene-1. Transl. Cancer Res. 2020, 9, 1195-1204. [CrossRef]

100. Aggarwal, B.B.; Yuan, W.; Li, S.; Gupta, S.C. Curcumin-free turmeric exhibits anti-inflammatory and anticancer activities: Identification of novel components of turmeric. Mol. Nutr. Food Res. 2013, 57, 1529-1542. [CrossRef]

101. Tafrihi, M.; Toosi, S.; Minaei, T.; Gohari, A.R.; Niknam, V.; Najafi, S.M.A. Anticancer properties of Teucrium persicum in PC-3 prostate cancer cells. Asian Pac. J. Cancer Prev. 2014, 15, 785-791. [CrossRef]

102. Husein, A.I.; Ali-Shtayeh, M.S.; Jondi, W.J.; Zatar, N.A.; Abu-Reidah, I.M.; Jamous, R.M. In vitro antioxidant and antitumor activities of six selected plants used in the Traditional Arabic Palestinian herbal medicine. Pharm. Biol. 2014, 52, 1249-1255. [CrossRef] [PubMed]

103. Ben Sghaier, M.; Ben Ismail, M.; Bouhlel, I.; Ghedira, K.; Chekir-Ghedira, L. Leaf Extracts From Teucrium Ramosissimum Protect Against DNA Damage in Human Lymphoblast Cell K562 and Enhance Antioxidant, Antigenotoxic and Antiproliferative Activity. Environ. Toxicol. Pharmacol. 2016, 44, 44-52. [CrossRef] [PubMed] 
104. Rajabalian, S. Methanolic extract of Teucrium polium L. potentiates the cytotoxic and apoptotic effects of anticancer drugs of vincristine, vinblastine and doxorubicin against a panel of cancerous cell lines. Exp. Oncol. 2008, 30, 133-138.

105. Eze, F.U.; Okoro, U.C.; Ugwu, D.I.; Okafor, S.N. Biological Activity Evaluation of Some New Benzenesulphonamide Derivatives. Front. Chem. 2019, 7, 634. [CrossRef]

Publisher's Note: MDPI stays neutral with regard to jurisdictional claims in published maps and institutional affiliations.

(C) 2020 by the authors. Licensee MDPI, Basel, Switzerland. This article is an open access article distributed under the terms and conditions of the Creative Commons Attribution (CC BY) license (http://creativecommons.org/licenses/by/4.0/). 